DANIEL J. B. MITCHELL

Brookings Institution

\title{
Union Wage Determination: Policy Implications and Outlook
}

FEW PROPESSIONAL ECONOMISTS would espouse the view that wage determination is the fundamental cause of inflation. But many economistsand certainly many policymakers-have the uneasy sense that the wage determination process contributes to the difficulty in checking the current inflation. Historically wages have been at the center of formal and informal intervention efforts. During the Kennedy and Johnson administrations the voluntary wage guidepost of 3.2 percent was the only absolute magnitude suggested by the Council of Economic Advisers. Prices were basically supposed to follow costs. Because most nonlabor costs are simply all other prices, the major constraint in the guidepost program on the inflation process operated through wages. A similar logic applied during the 1971-74 controls program when the 5.5 percent wage standard was promulgated by the Pay Board. ${ }^{1}$ Again, price controls were based primarily on cost markups so that the principal restraint on inflation was the impact of wage determination on costs. The new guidelines program

Note: I thank Thomas A. Gray for his assistance in compiling some of the data used in the regressions. The research was supported by a grant from the Alfred P. Sloan Foundation. This paper incorporates information about the Carter administration's new wage-price guidelines that were announced on October 24, after the Brookings panel meeting at which this paper was discussed.

1. For a discussion of the guidepost period, see John Sheahan, The Wage-Price Guideposts (Brookings Institution, 1967). The Pay Board experience is described in Arnold R. Weber and Daniel J. B. Mitchell, The Pay Board's Progress: Wage Controls in Phase 11 (Brookings Institution, 1978). 
announced by President Carter focuses on a wage standard of 7 percent, with price rules based on a mixture of cost markups and past pricing behavior.

\section{Union Wages}

In general, policymakers' concern about the labor market does not extend equally to all sectors. It is widely believed that, in the absence of legal constraints (such as minimum wages) or "threat" effects of potential union organization, nonunion employers will make their wage decisions according to the behavior of the labor market. But it is not clear that demand restraint would have the same impact on the unionized portion of the labor market.

If union wages are at a premium above what employers would unilaterally offer, union employers should have a queue of workers available to fill their vacancies, even in periods of high demand. Thus the observation that the queue is lengthening should not be of much interest to unionized employers. Nor should it be much of a factor in the bargaining strategy of the union. ${ }^{2}$ The demand for labor by a specific bargaining unit is likely to be quite inelastic, especially in the short run, so that wage moderation would have little influence in opening job opportunities or preventing layoffs. ${ }^{3}$ In any case, nonunion unemployed workers and even union members who have been laid off probably will not have a decisive voice in the internal political structure of the union.

The collective bargaining sector also is characterized by institutional features that are much less common among nonunion employers. Union contracts typically specify a fixed duration of two to three years. ${ }^{4}$ Thus

2. However, the business cycle could have indirect effects on the ability of strikers or their family members to obtain secondary incomes, on the employer's ability to pay, and on strike costs to the employer. For a more detailed discussion of this point, see Daniel J. B. Mitchell, "Union Wage Policies: The Ross-Dunlop Debate Reopened," Industrial Relations, vol. 11 (February 1972), pp. 46-61.

3. A recent study suggests that the possibilities of factor substitution for union production workers in manufacturing are relatively limited. See R. B. Freeman and J. L. Medoff, "Substitution between Production Labor and other Inputs in Unionized and Non-Unionized Manufacturing," discussion paper 581 (Harvard University, Harvard Institute of Economic Research, October 1977).

4. U.S. Bureau of Labor Statistics, Characteristics of Major Collective Bargaining Agreements, July 1, 1975, bulletin 1957 (Government Printing Office, 1977), pp. 7-8. 
decisions made in the past are at any point in time a substantial determinant of wage trends in the union sector. In 1977, a heavy bargaining year, only 40 percent of the workers in the major union sector (agreements covering 1,000 or more workers) received wage adjustments due to current settlements. Most of the remainder received adjustments from contracts adopted before $1977 .^{5}$

Cost-of-living escalator clauses are another special feature of the labor market that appear mainly in union wage agreements. Of the 9.7 million workers estimated to take part in major union agreements in the private sector, 5.8 million were covered by escalators in 1978. An additional 900,000 union workers participating in smaller agreements were also subject to escalation. ${ }^{\circ}$ The major union sector represents roughly half of the private union work force. Thus it is evident that escalator clauses are concentrated in the larger contracts. For example, all the so-called key contracts to be negotiated in 1979-trucking, rubber, electrical equipment, meat packing, and automobiles-currently include some form of an escalator clause. The only component of the major union sector in which escalation is generally absent is construction. There, the strong need of employers to know their labor costs in advance for bidding purposes drastically limits the proportion of workers with escalators.

Since the mid-1950s, the proportion of the labor force reported to be unionized has been shrinking. Measured against the total labor force, the proportion has fallen from over 25 percent at the end of the Korean War to 21.7 percent in 1974 , the latest year for which estimates are available. The figure would be higher if employee associations (organizations that dislike the label "union" but often engage in collective bargaining) and certain other groups were included. Employee associations are found mainly in government. In 1974, about 28 percent of wage and salary workers in the private nonfarm sector were members of some sort of organization representing employees. And because union workers tend to

5. Judith A. Finger, "Wage-rate Increases in Major Agreements in 1977 Smaller than Any Year Since 1973," Current Wage Developments, vol. 30 (April 1978), p. 53.

6. Douglas R. LeRoy, "Scheduled Wage Increases and Escalator Provisions in 1978," Monthly Labor Review, vol. 101 (January 1978), pp. 3-8.

7. U.S. Bureau of Labor Statistics, Directory of National Unions and Employee Associations, 1975, bulletin 1937 (GPO, 1977), p. 63; and U.S. Bureau of Labor Statistics, Handbook of Labor Statistics 1975-Reference Edition, bulletin 1865 (GPO, 1975), p. 389. 
earn more than nonunion workers, the union wage bill may account for about 35 percent of the total wage bill for the private nonfarm sector. ${ }^{8}$

It has been widely held that union wage decisions "spill over" into the nonunion sector, causing that sector to follow the collective bargaining pattern. ${ }^{\circ}$ Anecdotal evidence is easy to find concerning particular employers who automatically extend the union wage to their nonunion employees. But situations also exist in which nonunion wage decisions seem to "spill over" into the union sector. And some recent empirical work has tended to play down the importance of the spillover effect from union to nonunion. ${ }^{10}$

Even if an agnostic view of the magnitude of the union's ripple effect were taken, it would be difficult to imagine plausible theories in which the influence of increases in union wages on inflation is negative. ${ }^{11}$ Moreover, the inclusion in the union sector of large numbers of workers in individual situations makes it an inviting target for federal policymakers who are anxious to obtain a foothold somewhere in the wage-price spiral. This article sheds some light on a number of special features of the determina-

8. The Bureau of Labor Statistics estimates that there were $23,408,000$ members of unions (including locals affiliated directly with the AFL-CIO, local unaffiliated unions, and single-firm unions) and associations in 1974. If government and farm memberships are excluded, the estimate falls to $18,027,000$, which is 28 percent of payroll employment for the private nonfarm sector. See U.S. Bureau of Labor Statistics, Directory, pp. 63, 71, and Economic Report of the President, January 1978, p. 296. The 35 percent estimate is the weight of unionized workers in the employment cost index in December 1977.

9. See the remarks of John T. Dunlop in a recent debate on the utility of research in labor economics in which he argues that policymakers must take account of the spread of major union pattern-setting settlements. He argues that these settlements spread out to other union workers and indirectly to technical, managerial, and clerical employees by means of local salary surveys and internal company compensation plans. See John T. Dunlop, "Reply," Industrial and Labor Relations Review, vol. 31 (October 1977), p. 15. A recent report of the Council on Wage and Price Stability presents an equation "based on the premise that nonunion wages are a function of the unemployment rate and union wage increases." See U.S. Council on Wage and Price Stability, A Quarterly Report of the Council on Wage and Price Stability with a Special Report on Inflation, report 13 (GPO, 1978), pp. 45-46.

10. Robert Flanagan, "Wage Interdependence in Unionized Labor Markets," $B P E A$, 3:1976, pp. 635-73; and George E. Johnson, "The Determination of Wages in the Union and Non-union Sectors," British Journal of Industrial Relations, vol. 15 (July 1977), pp. 211-25.

11. One might argue that increases in union wages displace employment from the union to the nonunion sector, causing a nonunion deflationary effect. However, the significance of such an effect for short-run inflation dynamics is doubtful. 
tion of union wages and their policy implications, based on previously underutilized data sources. The paper concludes with an analysis of the outlook for the 1979 bargaining season and the new guidelines program.

\section{WAGB EQUATIONS}

Much of the research on wage equations has been aimed at improving the explanatory variables in aggregative equations. It is obviously important to identify the key independent variables in the wage-determination process. However, there is little in economic theory to guide the wage researcher beyond the general proposition that some measure of inflation and of real business conditions ought to be included. Modern computer technology makes the search for equations with better fit too easy.

An alternative approach is to limit the independent variables to some straightforward proxies for inflation and business conditions and to disaggregate the wage series in ways that follow labor-market institutions. The loss in elegance may well be balanced by a gain in insight. However, the difficulty in the disaggregated approach is finding data sources that follow institutional forms. In particular, it is desirable to distinguish between wage adjustments in union and in nonunion situations. And within the union sector, it would be convenient to distinguish between wage adjustments that reflect contemporary decisions (new contract negotiations) and those that result from earlier decisions (deferred and escalator adjustments near the end of the contract's duration). It is obvious, for example, that the second and third year of a nonescalated contract cannot be influenced by unanticipated changes in economic circumstances, except in the special case in which both parties agree to abandon the specified terms of the agreement. Wage adjustments in the second and third years of an escalated contract are mechanically influenced by movements in the consumer price index (CPI), but by no other unanticipated contemporary variables.

Two data sources are used in this article to capture these institutional features in the labor market. The first is a measure of changes in wage rates for manufacturing prepared by the U.S. Bureau of Labor Statistics, which can be significantly disaggregated to provide indexes of wage movements for union and nonunion establishments and for new and deferred wage changes. The second is a file of agreements of large union situations covering changes in wage rates for selected units in the manufacturing, 
mining, and transportation industries. It is unfortunate that neither data set includes adjustments for fringe benefits, an important element of union compensation.

\section{Wage Changes in Manufacturing}

Since 1959, the Bureau of Labor Statistics has published data on manufacturing establishments that make general wage adjustments. ${ }^{12}$ The series measures median changes in wage rates for production workers in the union and nonunion sectors. Wage changes are given as "effective" changes (resulting from first-year, deferred, and escalator adjustments) and as first-year adjustments alone. A separate tabulation is provided for the major union sector, which also lists effective and first-year adjustments. Most nonunion adjustments are essentially first-year changes because nonunion employers are unlikely to make long-term unilateral commitments. Thus only the effective changes for the nonunion sector are considered here. ${ }^{13}$

The BLS provides data on both the number of workers covered by first-year changes and those protected by effective changes. This information is used to estimate additional wage changes for deferred and escalator adjustments in the major union sector and for first-year and deferred adjustments in the "minor" (nonmajor) union sector (workers in union establishments not covered by agreements involving 1,000 or more workers). However, these estimates are imprecise for two reasons. First, for the years in which the mean data are available, the means and medians are not identical, although they are closely associated. As an example, during the limited period when both the mean and the median data were available for the major union sector, the medians understated the mean first-year adjustments by an average of about 0.6 percentage point and effective changes by less than 0.4 percentage point. Thus if the medians are used as if they were means to predict deferred adjustments from firstyear and effective changes, estimated deferred adjustments will be slightly overstated.

Second, workers who receive first-year increases may also receive de-

12. The data appear in Current Wage Developments, various issues.

13. Effective and first-year nonunion median wage changes rarely deviate by more than 0.3 percentage point. 
cause it adjusts for changes in the composition of the labor force that have affected the relationship between observed unemployment and the "looseness" or "tightness" of the labor market. However, the two rates are highly intercorrelated $(R=0.9)$ over the observation period, and the autoregressive correction used in the estimation of the equations tends to eliminate the impact of the trend divergence of those rates. In addition, the rates have different average levels, and therefore produce coefficients of $U^{-1}$ of different magnitudes. This makes the equations using weighted unemployment somewhat cumbersome if a translation in terms of the official rate is desired for policy purposes. For this reason, only the equations using the official unemployment rate are discussed. ${ }^{17}$

Various lag structures were used for the price and unemployment variables. As noted above, escalator coverage is concentrated in the larger contracts. Hence signs of escalator influence should be expected in equations based on the series of deferred adjustments in the major union sector.

\section{STATISTICAL ESTIMATES}

Table 1 provides a summary of the regression results. The nonunion sector in row 5 of the table exhibits the expected sensitivity to real business conditions. At 6 percent official unemployment, row 5 suggests that increases in the nonunion wage rate would be slowed by 0.4 percentage point if there were a 1 percentage point increase in the unemployment rate. The coefficient for $p_{-1}$ indicates that a 1 percentage point rise in price inflation translates into an increase of roughly 0.6 percentage point in nonunion wage inflation.

17. The use of the unemployment rate is simply intended as a proxy for real business conditions. Other indicators were tested with similar results: the quit rate in manufacturing, the inverse of the unemployment rate for white males aged 3544, and the ratio of real gross national product to its logarithmic trend. Experiments inserting the year-to-year change in the unemployment rate generally produced insignificant coefficients. When a lagged variable representing the ratio of profits to sales was added to the equations, it usually produced negative coefficients. This result is understandable because wage increases are a potential subtraction from profits and because changes in both profits and wages are highly correlated with their lagged values. It is possible that profits, when viewed as an index of ability to pay, do influence wage movements, but that simple equations do not pick up the effect. Experiments suggested by some Brookings panel members using lagged changes in money supply rather than in prices generally produced insignificant coefficients of money supply. 
ferred increases in the same year. A worker who received a first-year adjustment under a new contract on, say, July 1, 1970, might also have received a deferred or escalator adjustment on January 1,1970, under the previous expiring contract. The worker might also receive an escalator adjustment on December 31,1970, under the new contract. Thus if the number of workers receiving deferred and escalator adjustments is calculated by subtracting the number receiving first-year adjustments from those receiving effective adjustments, the deferred and escalator population will be understated. As a result, the estimated deferred and escalator increase will be overstated, especially during periods when escalator increases are high. ${ }^{14}$

Despite these difficulties, it seems reasonable to estimate the unknown components of union wages with the available data, and then to interpret the results with the data limitations in mind. At least some potential problems can be alleviated by reference to the data on a sample of contracts discussed in the next section. Six data series were taken or estimated from the BLS manufacturing data: first-year adjustments (excluding escalator adjustments) in the major union sector; first-year adjustments in the minor union sector; deferred and escalator adjustments (hereafter denoted "deferred") in the major union sector; deferred adjustments in the minor union sector; nonunion effective wage changes; and effective wage changes for the combined union and nonunion sectors. ${ }^{15}$

Wage changes for 1960-76 were regressed in annual equations against the year-to-year percent changes in the CPI $(p)$ and the inverse of the unemployment rate $\left(U^{-1}\right)$. Two forms of the unemployment rate were tested: the official rate and the weighted Perry rate. ${ }^{10}$ The weighted unemployment rate is a conceptual improvement over the official rate be-

14. This problem is distinct from the one to be discussed below in which deferred adjustments in escalated contracts from the union contract data are underestimated.

15. Data were available directly for effective and first-year adjustments (including zero and negative adjustments) for major union situations and all union situations. Using employment weights, the implicit minor first-year adjustments were calculated. Available data on effective wage adjustments for major union situations and on firstyear adjustments were used to calculate the implicit deferred adjustment for major unions (including escalator adjustments). Existing data on effective adjustments and first-year adjustments for all union situations were used to calculate effective minor union adjustments, and these were combined with the estimates of minor first-year adjustments to calculate the implicit minor deferred adjustments.

16. For a description of the Perry unemployment rate, see George L. Perry, "Changing Labor Markets and Inflation," BPEA, 3: 1970, pp. 411-41. 


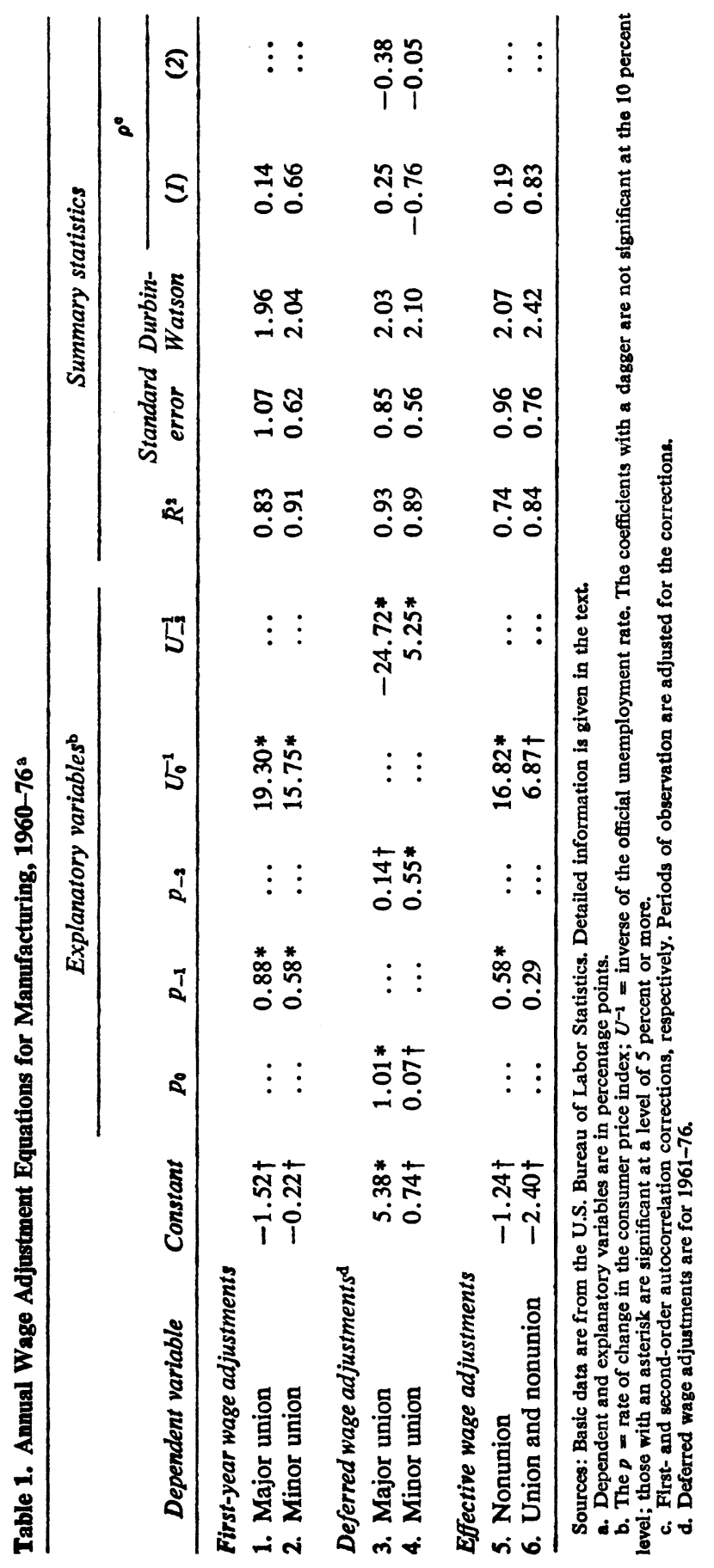


The most interesting results in the table relate to the union sector. First-year adjustments in both the major and minor components show roughly the same sensitivity to unemployment as the nonunion sector. One appealing interpretation of this finding is that the initial increase in long-term agreements reflects real business conditions at the time of negotiations. However, the following section presents evidence that the apparent sensitivity does not derive from long-term agreements, but rather from short-term agreements in which the first-year increment constitutes most or all of the wage change for the entire life of the contract. Nevertheless, the concentration of unemployment sensitivity in short-term agreements does not necessarily mean that participants in long-term contracts are insensitive. In some cases they may react to aberrations in what they perceive as temporary economic circumstances by adopting a shortterm (temporary) agreement, presumably to be followed by a long-term agreement when the economic climate changes.

Both the major and minor sectors show sensitivity to lagged price change, $p_{-1}$, although the coefficient for the major union sector is larger than the coefficient for the minor union and nonunion sectors and is close to unity. Given the crudeness of the data and equations, there seems little difference, however, between the short-term pattern in nonunion and first-year union wage adjustments.

It is in the deferred component of the union sector that important differences between the union and nonunion sector can be seen. Before exploring these, it is essential to note that estimates of the deferred wage adjustment are dominated by past wage decisions, including previous decisions to use contingency arrangements. Because on average union contracts are effective for two to three years, variables used to explain deferred adjustments must be lagged. The equations in the table assume that the appropriate lag is two years. Exceptions must be made, however, for escalator contingency clauses associated with the CPI. For contracts with such clauses, the current rate of price change $\left(p_{0}\right)$ is clearly necessary for explanatory purposes.

The major union sector is associated with cost-of-living escalation. It is not surprising then that contemporary price inflation occurs as a significant explanatory variable in row 3. (The magnitude of the coefficient is discussed below.) Escalation is much less frequent in the minor union sector; thus contemporary price change should not be expected to have 
much infiuence on the deferred portion of the contract. And, indeed, the coefficient of $p_{0}$ in row 4 is essentially zero. Apart from escalator effects, deferred wage changes might reflect price inflation at roughly the original contract negotiation date, that is, $p_{-2}$. The minor union sector, where escalation is less common, in fact does exhibit a significant coefficient for $p_{-2}$ with a magnitude approximately equal to the coefficient for $p_{-1}$ in the firstyear equation. Row 4 seems to imply that wages in the nonescalated sector in all years of the contract react similarly to the price inflation that had occurred when the agreement was signed. One interpretation is that nonescalated contracts carry inflation assumptions from the past into the future. Another is that they catch up with price inflation gradually. The escalated major union sector shows virtually no sensitivity to lagged inflation in the deferred element of the contract. Negotiators evidently are willing to rely mainly upon escalators to handle future inflation.

What is puzzling about the major union sector's deferred performance is the magnitude of the coefficient of $p_{0}$. The unitary coefficient is larger than studies of actual union escalator clauses suggest it should be. One study, for example, found that escalators typically provided a 0.57 percent wage increase for each 1 percent of CPI inflation. ${ }^{18}$ This less-thanproportional relationship is the result of the formulas that are applied and the special limitations placed on the actual operation of the formulas.

A common escalator formula at present is 1 cent an hour for each 0.3 index-point increase in the CPI $(1967=100)$. In June 1978 , the CPI for urban wage and clerical workers was 195.3. A 0.3 point increase therefore translates into a 0.15 percent price increase. Thus at a wage level of about $\$ 6.50$ an hour the formula would just compensate for inflation, but many union workers earn more than this amount. In addition, "corridors" and limitations on the absolute amount of escalator payoff require some inflation to occur before payoff begins; such features move escalators further from proportionality. From a bargaining viewpoint, escalators add uncertainty to the costs of employers who may need accurate projections of future nominal costs for bidding and planning. Moreover, escalators may be designed to obscure their limitations from union membership (for example, by shifting from index points to percentage points without

18. See Victor J. Sheifer, "Collective Bargaining and the CPI: Escalation vs. Catch-Up," in Industrial Relations Research Association Series, Proceedings of the August 1978 Meeting (forthcoming). 
changing the cent-per-hour payoff) ${ }^{19}$ In short, the escalator formulas reflect bargaining compromises.

The issue remains of why the estimated coefficient of $p_{0}$ in row 3 is so large. Its magnitude appears to stem primarily from the method of estimation of deferred wage adjustments rather than from any structural relationship. It was noted above that the deferred wage estimate tends to be relatively overstated in periods when escalators take on importance in the total deferred wage adjustment. This effect occurs because the number of workers receiving such increases will be more understated during these periods. Escalators do become more important if many workers are covered by escalators and if escalators pay large amounts. Both these circumstances tend to arise during periods of rapid inflation. And this effect tends to bias the coefficient upward. If the period 1973-76 is dropped from the equation in row 3 , for example, the coefficient falls to $0.51 .^{20}$

The reaction of deferred wage changes to lagged unemployment $\left(U_{-2}^{-1}\right)-$ that is, to unemployment at the time of negotiations-raises some interesting issues. In the minor union sector, the unemployment coefficient has the right sign and is significant. But it is much smaller than for first-year changes. If the coefficient for the life-of-contract wage change of a twoyear agreement in the minor union sector consists of an average of the first-year and deferred reaction coefficients (in this case, 10.5), a 1 percentage point increase in the official unemployment rate from a 6 percent level would cut the life-of-contract wage increase by only one-fourth of 1 percent. The reaction would be even smaller in a three-year contract.

For the major union sector, the deferred unemployment coefficient exhibits the "wrong" sign (table 1, row 3 ) and, taken literally, would outweigh the first-year coefficient in a contract of two or three years' dura-

19. The most creative escalator of the past few years appears is the 1976 contracts of General Electric Company. Wages were to rise 1 cent an hour for each 0.3 percent (not each index point) increase in the CPI up to 7 percent and above 9 percent with no credit for the gap between 7 and 9 percent. See "Wage Highlights," Current Wage Developments, vol. 28 (July 1976), p. 1.

20. The estimated equation is:

$$
\begin{gathered}
M D E F=3.73+0.51 p_{0}+0.36 p_{-2}-12.55 U_{-2}^{-1}, \\
\text { Durbin-Watson }=2.27 ; R^{2}=0.81 ; \text { standard error }=0.43 ; \rho(1)=0.07 ; \rho(2)=-0.01,
\end{gathered}
$$

where $M D E F$ is estimated deferred adjustments in the major union sector. The constant and first two coefficients are significant at a level of 5 percent or more. The lagged price coefficient increases in magnitude and significance, presumably because the major union sector had less escalation in the earlier period. 
tion. The perverse reaction to unemployment appears again to be due to the method of calculating deferred increases. Beginning in 1973, estimated deferred increases become quite large, while at the same time unemployment rises. Escalator clauses, mirroring the inflation in prices, would have substantially raised the deferred component of the major union sector. But as noted, the method of calculation tends to exaggerate deferred wage increases as escalators become more significant. And this exaggeration coincides with a period of high unemployment. Omitting the 1973-76 period reduces both the magnitude and significance of the unemployment coefficient. ${ }^{21}$

If the coefficient of $U_{-2}^{-1}$ in row 3 were zero, the impact of unemployment on the wage change over the life of the contract would still be quite small-roughly comparable to the life-of-contract estimate for the minor union sector. In any given year, substantial numbers of major and minor union workers would receive only deferred adjustments, which could not react to current unemployment and apparently do not reflect past unemployment. This result is in sharp contrast to the nonunion sector in which the option to change wages in response to current circumstances is always available.

A final point on the wage equations for manufacturing is worth mention. Row 6 of table 1 presents an aggregate equation that offers an explanation of the effective wage changes in manufacturing. The dependent variable includes both union and nonunion sectors; the union sector comprises first-year and deferred adjustments. The result of using an equation in aggregate form is a regression with an implausibly low (and barely significant) price coefficient; such a regression depends largely on the autoregressive properties of wage data for its explanatory power. It appears, therefore, that aggregate equations which take no account of labor-market institutions are likely to miss important elements of the wage-determination process.

\section{Evidence from Union Contract Data}

In recent years a number of empirical studies of union wage determination have been conducted, based on observations of samples of individual

21. The coefficient of $U-1$ in the equation of note 20 falls just below significance at the 10 percent level. 
agreements rather than on general wage indexes. ${ }^{22}$ The use of contract data has many advantages. These data permit explicit division of the sample into long-term, short-term, escalated, and nonescalated agreements. Even the wage data presented in the previous section could not directly be disaggregated at such a level of detail. Knowledge of the timing of negotiations permits the design of explanatory variables to be more closely related to this timing.

Contract data are not easy to obtain. Although the BLS maintains a file of contracts for its own costing purposes, the cost information contained therein is confidential and is not available to the public for individual agreements. However, the BLS does make available a wage chronology for each of a number of important collective bargaining situations. In addition, its periodical, Current Wage Developments, provides data on reported wage increases in individual union situations. These two sources, however, most frequently report wage increments in terms of cents per hour. The information on fringe benefits does not allow costing of the benefits. And although the chronologies provide information on some occupational categories, there are no data available on the average base wage prior to the start of the contract.

Despite this lack of precise information, the advantages of using contracts rather than time periods as observations suggest that estimates of the wage costs are worth the effort, partly as a check against the results obtained in the previous section. Consequently, estimates were made of the wage-rate increments in 172 union contracts negotiated by 17 major employers or employer associations during 1954-76, primarily from information contained in the wage chronologies. Contracts included manufacturing, mining, and transportation situations and are listed in table A-1 in the appendix.

22. See Daniel S. Hamermesh, "Wage Bargains, Threshold Effects, and the Phillips Curve," Quarterly Journal of Economics, vol. 84 (August 1970), pp. 50117; Daniel S. Hamermesh, "Market Power and Wage Inflation," Southern Economic Journal, vol. 39 (October 1972), pp. 204-12; Gordon R. Sparks and David A. Wilton, "Determinants of Negotiated Wage Increases: An Empirical Analysis," Econometrica, vol. 39 (September 1971), pp. 739-50; and L. N. Christofides, R. Swidinsky, and D. A. Wilton, "A Micro Econometric Analysis of the Canadian Wage Determination Process (1966-75)" (University of Guelph, April 1978). Contract data have also been used to analyze nonwage outcomes. See Thomas A. Kochan and Richard N. Block, "An Interindustry Analysis of Bargaining Outcomes: Preliminary Evidence from Two-Digit Industries," Quarterly Journal of Economics, vol. 91 (August 1977), pp. 431-52. 
Three measures of wage change were computed and converted into annualized percentage rates, based on average hourly earnings for the relevant industry classification. FIRST is used to indicate percentage change in wage rates scheduled as general adjustments of wages during the first twelve months of the contract. These estimates generally exclude both "inequity" adjustments made to particular subgroups of workers and escalator increases. LIFE denotes annualized percentage change from general adjustments of wages and escalator payments over the entire life of the contract. Inequity adjustments are generally excluded.

$D E F E R R E D$ is annualized percentage change from general adjustments of wages and escalator payments over the life of the contract, excluding the increments reported in FIRST. Because escalator payments often occur during the first year, the annualization period for escalated contracts is the full life of the contract. For nonescalated contracts, the annualization period is the life of the contract minus twelve months. $D E$ FERRED was not computed for contracts of less than eighteen months (none of which were escalated in the sample). ${ }^{23}$

23. In the previous section a problem of estimating deferred adjustments was noted concerning inaccurate estimates of the number of workers affected. In this section, a different problem arises because escalator clauses may activate during the first twelve months of the contract. For nonescalated contracts the deferred portion of the contract should be annualized over the contract duration minus twelve months. Because escalators can be effective in the first year, the deferred portion of escalated contracts must be annualized over the full contract. This procedure understates the percentage rate of change of the deferred component of an escalated contract relative to that of a nonescalated contract. Imagine two agreements of twenty-four months, one escalated and the other nonescalated. Suppose both called for semiannual adjustments beginning with the first day of the contract, and suppose further that both increased wages by 3 percent every six months. But suppose that the escalated contract called for 1 percent fixed increase each six months and the remaining 2 percent came from the escalator. Both would have a value of $L I F E=6.1$ percent. The escalated contract would have a value of FIRST $=2.0$ percent because no escalator increases are assigned to FIRST, while the nonescalated contract would show $F I R S T=6.1$ percent. The escalated contract would provide for deferred increases of 2 percent, 2 percent, 3 percent, and 3 percent over twenty-four months. This would produce a value of DEFERRED $=5.1$ percent. For the nonescalated contract, the final two increases of 3 percent would be spread over twelve months, producing a value of $D E F E R R E D=6.1$ percent. In short, due to the treatment of the escalator increase, a first-year increase of 2.0 percent and a deferred increase of 5.1 percent would be associated with a life-of-contract annualized increase averaging 6.1 percent. The alternative procedure of annualizing the deferred component of the escalated contract over only the last twelve months of the contract would overstate the rate of increase during that period. Another possibility would be simply to 
In addition to the data on general adjustments of wages, the wage chronologies provide some information on wage rates paid to specific occupational groups. It is possible that, because of special "inequity" adjustments, over time certain groups of workers experience different rates of percentage wage changes. An interesting question is whether the forces that explain general changes in wages have a systematic effect on relative wages by skill class. A narrowing of skill differentials, for example, might give rise to dissatisfaction among some workers, an ongoing problem in certain industrial unions. Such dissent can complicate the bargaining process and hinder contract ratification, as it did at the Ford Motor Company in 1973.24

To address the issue of wage structure, three additional measures of wage change were computed for contracts having the necessary data available. An annualized percentage increase in wage rates over the life of the contract is denoted $L O W$ for an occupation at the bottom of the wage structure (for example, a position corresponding to janitor); $M E D I U M$ for an occupation in the middle of the wage structure; and $H I G H$ for an occupation toward the top of the wage structure.

Four independent variables were initially used to explain wage changes according to these various measures for all contracts with durations of at least eleven months. ${ }^{25}$ Three of these correspond to the variables used in the previous section. These are $p_{-1}$, the year-to-year percentage increase in the CPI lagged one year before the effective date of the contract; $U_{0}^{-1}$, the inverse of the official unemployment rate in the year the contract became effective; and $\operatorname{COLA}$, the annualized percentage rate of change of the CPI over the life of the contract if the contract has an escalator or

allocate escalated increments during the first year to FIRST, although this procedure differs from the methodology used by the BLS in preparing the manufacturing estimates that appear in table 1 . The problem occurring in the estimation of FIRST is minimized because escalated contracts often include a fixed rather than an escalator adjustment as a large fraction of their first-year adjustments. The problem disappears when $L I F E$ is used as the dependent variable.

24. A number of industrial unions have had skilled trades problems. For background, see Arnold R. Weber, "The Craft-Industrial Issue Revisited: A Study of Union Government," Industrial and Labor Relations Review, vol. 16 (April 1963), pp. 381-404. The issue at Ford in 1973 involved voluntary overtime rather than wage differentials per se. During the 1960s, the National Labor Relations Board tightened its criteria used in considering craft petitions for severance from existing industrial units, thus lessening the pressure on unions to deal with the concerns of skilled trades.

25. Agreements of less than eleven months were excluded because they often represented interim adjustments granted while negotiations progressed. 
zero if it has no escalator. A fourth variable, $R E L$, is an index of the relative wage status of a particular industry prior to the effective date of the contract. ${ }^{26}$

The use of the first three variables is straightforward and requires no justification. However, the REL variable had no counterpart in the previous section and requires discussion. Some of the literature on wage determination suggests that wages in different industries are linked together. Wide-reaching patterns are occasionally said to tie settlements together. ${ }^{27}$ Often one finds references to "catch-up" pressure affecting wage settlements, although it is not always clear whether the catch-up involved is relative to prices or wages. ${ }^{28}$ And generally it might be argued that interindustry wage differentials are limited in the degree to which they can vary by the potential for substitution in both product and labor markets.

Any or all of these considerations would lead to the expectation that a group of workers that had fallen "behind" its "normal" standing in the interindustry wage structure would speed up its rate of wage increase, all other things being equal. Similarly, a group that was "ahead" would slow down. ${ }^{29}$ Thus a negative coefficient of $R E L$ is expected. It would simply

26. As in the previous section, estimates of the equations were calculated with both the official rate of unemployment, $U_{0}^{-1}$, and the Perry weighted rate of unemployment. Again, the two rates are highly correlated so that virtually the same results were obtained for both. The equations below use the official rate. $R E L$ was computed by dividing the base earnings (used to compute percentage changes for FIRST, LIFE, and DEFERRED) by average hourly earnings for the private nonfarm sector in the year prior to the effective date of the contract, and then standardizing the ratio by dividing it by its mean value for all contracts of the same employer in the sample.

27. Otto Eckstein and Thomas A. Wilson, "The Determination of Money Wages in American Industry," Quarterly Journal of Economics, vol. 76 (August 1962), pp. 379-414; John E. Maher, "The Wage Pattern in the United States, 1946-1957," Industrial and Labor Relations Review, vol. 15 (October 1961), pp. 3-20.

28. Marvin Kosters, Kenneth Fedor, and Albert Eckstein, "Collective Bargaining Settlements and the Wage Structure," Labor Law Journal, vol. 24 (August 1973), pp. 517-25.

29. This hypothesis should be distinguished from a seemingly related proposition that is sometimes found in the literature, which asserts that a "distortion" of the wage structure leads to a generalized increase in the rate of wage change. See Arnold H. Packer and Seong H. Park, "Distortions in Relative Wages and Shifts in the Phillips Curve," Review of Economics and Statistics, vol. 55 (February 1973), pp. 16-22. A second proposition that must be differentiated is that distortions in the rate of wage increase generally contribute to faster wage increases, presumably through some sort of competitive, leapfrogging process. See D. Q. Mills, "Explaining Pay Increases in Construction: 1953-1972," Industrial Relations, vol. 13 (May 1974), pp. 196-201. The hypothesis in the text applies only to a particular unit that is out of line from its traditional position in the wage structure. 
indicate a tendency for relative wage differences to be maintained. Such a finding would not differentiate between competing explanations for such a tendency, nor would it preclude changes in wage differentials across industries over long periods of time.

\section{Statistical Estimates}

Analysis of the earlier regressions from the manufacturing sector suggested that wage change in major union contracts would be sensitive to lagged price change. It also suggested that sensitivity to an indicator of business conditions such as unemployment would be found in first-year adjustments, but that this sensitivity would not be characteristic over the life of the contract. Table 2 presents regression results from the contract sample against which the earlier conclusions can be checked.

Equation 1 in the table presents the overall results for FIRST for all contracts in the sample. The coefficients for $p_{-1}$ and $U_{0}^{-1}$ are almost identical to those appearing in row 1 of table 1 . In addition, table 2 permits examination of the relative wage hypothesis, which could not be tested using the aggregate data of table 1. As expected, REL has a negative sign and is statistically significant. Taken literally, the coefficient of REL suggests that if wages in a unit were 10 percent above normal prior to negotiations $(R E L=1.10)$, wages would increase about two percentage points more slowly in the first year than they would if relative wage standing were normal $(R E L=1.00) . .^{30}$

Table 1 did not provide a direct measure of the LIFE variable. However, it did suggest that the deferred portion of the package was not sensitive to price change at the time of negotiation and that the reaction to unemployment was, if anything, perverse. Equation 3 of table 2 suggests that, over the life of the contract, sensitivity to price change prior to negotiation is a characteristic of labor contracts and that sensitivity to

30. The relative wage variable was entered in the regressions in ratio form rather than as a wage premium. That is, an industry with wages 1 percent above normal has $R E L=1.01$ rather than 0.01 . Because $R E L$ averages unity in value, it receives a large coefficient that is counteracted by a constant term of opposite sign and similar absolute magnitude. This in no way changes the interpretation of the $R E L$ coefficient as the derivative of wage change with respect to $R E L$. The effect of a 1 percent increase in relative wage status is simply 0.01 times the coefficient of REL. 
unemployment can also be found. These findings do not contradict those of table 1. If $p_{-1}$ affects only the first year of short-term contracts, it will still have an influence on LIFE. (The wage increase over the life of the contract in agreements of short duration includes the first-year adjustment as a major element.)

The issue of sensitivity to unemployment can be clarified by explicitly dividing the sample into short-term contracts (eleven to seventeen months) and long-term contracts (eighteen months or more). Equations 5 and 7 indicate that the short-term contracts show extremely high sensitivity to unemployment. For example, equation 7 suggests that a 1 percentage point increase in the official unemployment rate from a 6 percent level would slow life-of-contract wage change by 1.2 percentage points. In contrast, none of the equations for long-term contracts shows statistically significant wage changes as a response to unemployment, either in the first year or in the life of the contract.

One possible interpretation of the apparent relationship between contract duration and unemployment sensitivity is that short-term contracts tend to be concentrated in the earlier part of the period. Of the 61 shortterm contracts, 47 were negotiated before 1965 . Moreover, several of the later short-term contracts resulted from interruptions of contracts of longer duration that occurred when the parties reopened existing agreements. For whatever reason, it appears that in the early part of the period the parties were more likely to be under pressure to adjust to real business conditions, and that they reacted by using short-term contracts as the vehicle for adaptation. ${ }^{81}$

A second possibility involves running the causal arrows in the other direction. Long-term contracts represent a procedure for minimizing transactions costs. The most obvious cost that is reduced is the threat of a strike. For situations where the risks of being locked into a long-term

31. Although the short-term contracts in the sample are concentrated in the earlier part of the period, there is evidence that contract duration is still affected by adverse conditions in the unionized labor market. For example, during the last few years when American Motors had financial difficulties, the United Auto Workers granted the company certain concessions in the context of short-term contracts. In September 1978, when the economic outlook for the company brightened, the parties concluded a two-year agreement that eliminates some of the concessions of the past. The wage-price controls initiated in 1971 were apparently viewed by the unionized sector as a temporary change in economic circumstances and a notable shift to shorter-term contracts occurred. See Weber and Mitchell, The Pay Board's Progress, pp. 363-65. 


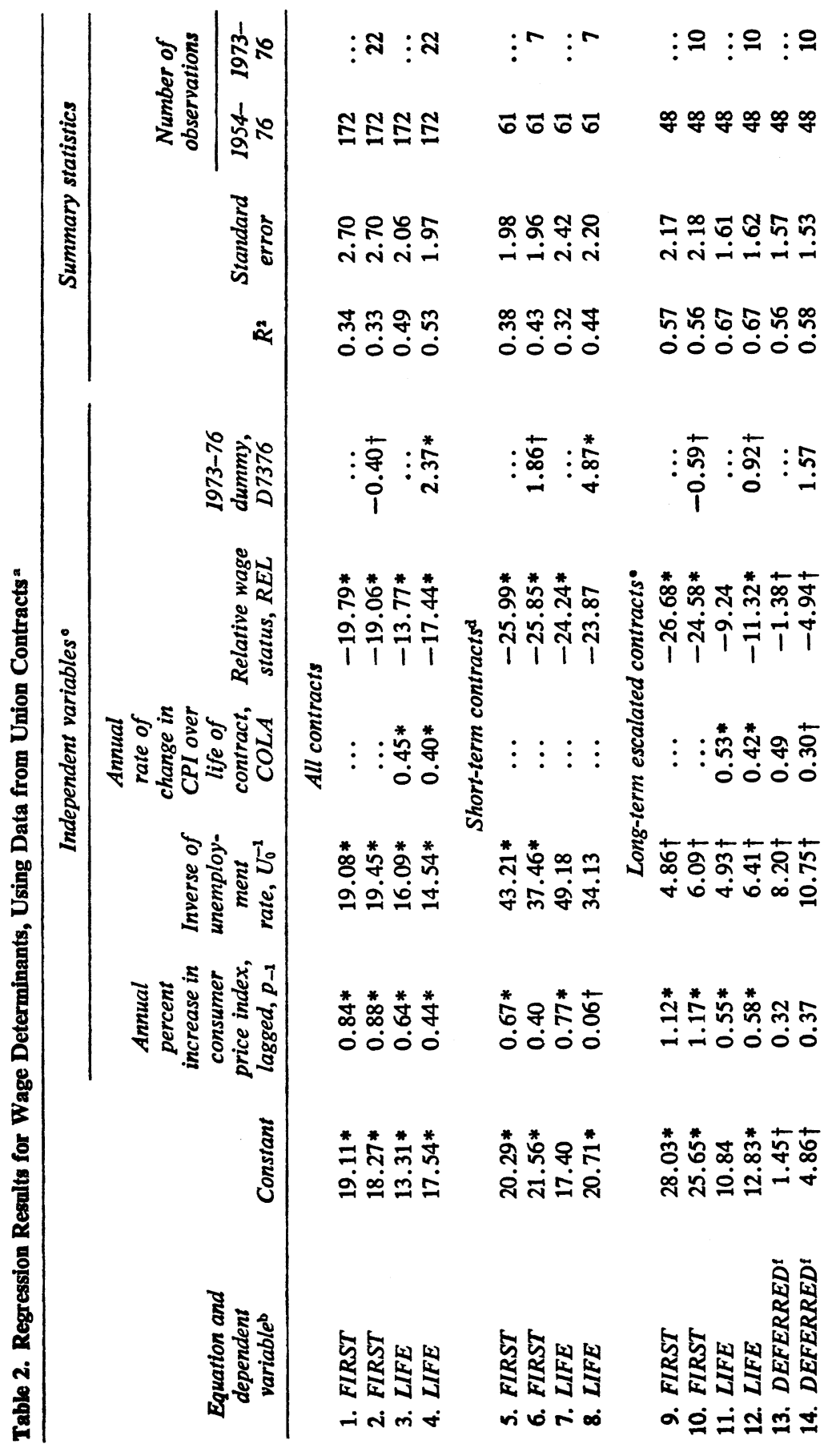




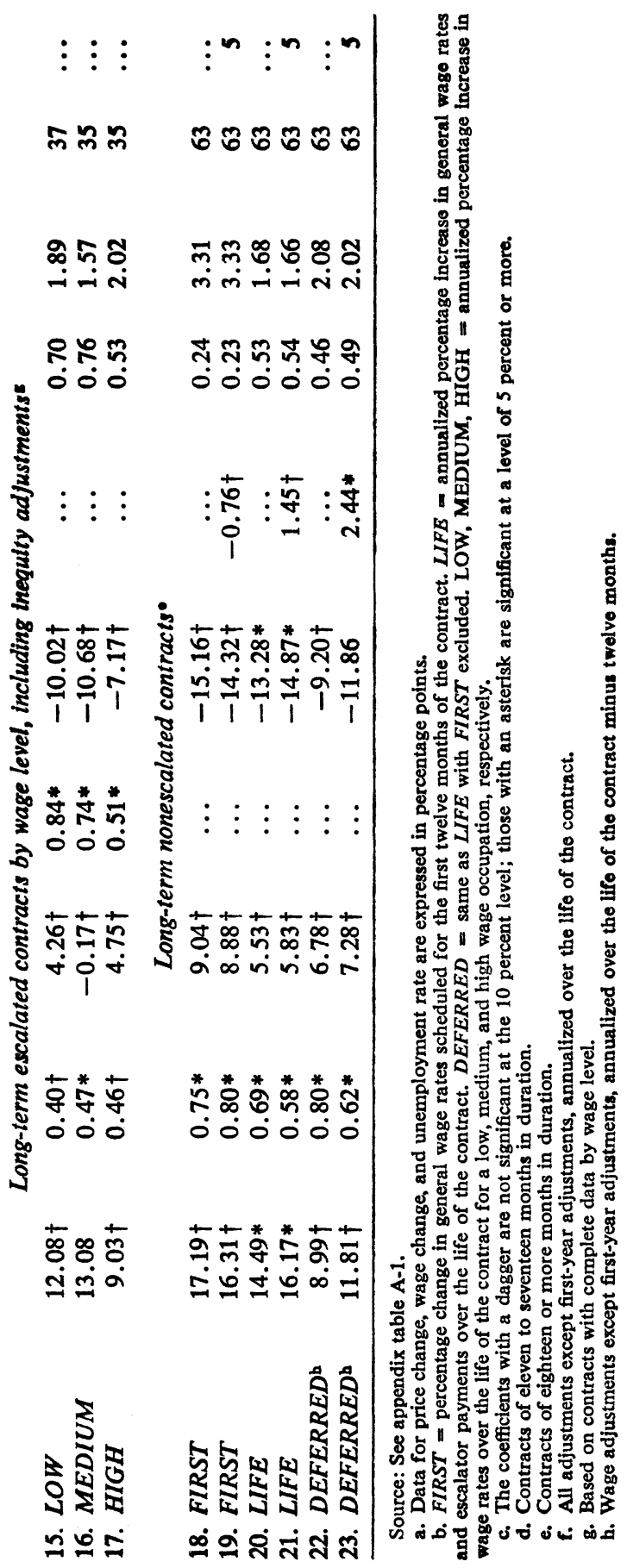


arrangement in which wages may deviate from the desired path are not seen as especially perilous, the reduction of transactions costs is attractive. Once the decision is made to take a long-term view, it is natural to expect that wages would not reflect transitory business conditions that happened to exist at the moment of negotiations. Instead, the parties would take an averaging perspective.

Those whose prior expectations call for unitary price coefficients will get support from 11 in table 2 . In a steady-state inflation for escalated contracts, $p_{-1}$ would be equal to $C O L A$. The coefficients for these two variables $(0.55$ and 0.53$)$ sum approximately to unity. In short, the equation suggests that economic units which express an overt interest in prices by mechanically tying their wages to the CPI do make real wages immune from price inflation. The units that do not openly express an interest in pricing (the short-term and the long-term nonescalated contracts) have price coefficients that fall short of unity. Nevertheless, it might be argued that the tendency in recent years for the spread of escalation shows that previously nonescalated groups are willing to "come out of the closet" and expose their price orientation to anyone who cares to look when inflation becomes a sufficient concern. That is, they move from the groups represented by 7 and 20 in which real wages are vulnerable to price inflation to the group represented by equation 11, in which they are not.

Wage Differentials. Equations 15, 16, and 17 demonstrate the impact of escalation on internal wage differentials. In long-term escalated contracts, the coefficients of $C O L A$ tend to be higher for low-wage occupations than for high-wage occupations. This shows the tendency of escalator formulas to provide cents-per-hour increases rather than percentage increases across the entire wage structure. Thus in periods when escalator increments are important, escalators compress the wage structure. This tendency does not necessarily mean that high-wage workers lose in real purchasing power due to inadequate escalation because nonescalator increments and special inequity adjustments may also be provided. Taken literally, the sum of the coefficients of $p_{-1}$ and $C O L A$ in 17 suggests that high-wage workers are fully compensated for steady-state inflation by the totality of the wage package. (Low- and medium-wage workers are overcompensated if the coefficients of 15 and 16 are accepted at face value.) But relative wage compression could provide grounds for dissatisfaction and stress on the union political structure and on internal incentives.

Table 3 presents a breakdown of the 106 contracts in which all data for the $L O W, M E D I U M$, and HIGH variables were available. There is 
Table 3. Mean Annualized Rate of Wage Increase at Selected Wage Levels, 1954-76"

Percent

\begin{tabular}{lccc}
\hline & \multicolumn{3}{c}{ Type of contract } \\
\cline { 2 - 4 } Variable $^{\mathrm{b}}$ & All & Escalated & Nonescalated \\
\hline LOW & 6.0 & 7.8 & 5.2 \\
MEDIUM & 5.6 & 7.1 & 4.9 \\
HIGH & 5.4 & 6.5 & 4.8 \\
LIFE $^{\mathrm{b}}$ & 5.3 & 6.7 & 4.7 \\
\hline
\end{tabular}

Source: See appendix table A-1.

a. Includes 35 observations for escalated and 71 for nonescalated, for a total of 106.

b. The variables are defined in table 2 , note $b$.

c. Defined as in table 2, but based on contracts with complete data used to compute LOW, MEDIUM, and $H I G H$ categories.

an apparent tendency for wage differentials to narrow in both escalated and nonescalated contracts. (Wages can rise faster for these variables than for $L I F E$ due to periodic inequity adjustments.) However, the gap in the rate of wage change between high- and low-wage workers is substantially larger in the escalated group of contracts than in the nonescalated group. Over a ten-year period, the 0.4 percent gap for the nonescalated contracts would result in an increase of a little over 4 percent in the ratio between low-wage and high-wage workers. The 1.3 percent gap for the escalated contracts would result in an increase of 14 percent in the ratio.

Over the long run, there has been a gradual narrowing of skill differentials throughout the economy. ${ }^{32}$ It does appear, however, that the escalator mechanism aggravates this trend and that inequity adjustments given to high-wage workers do not fully offset the escalator effect. If inflation continues at a rapid rate, either escalator formulas will be modified to provide percentage increases or inequity adjustments for high-wage workers will become more routine. Some escalator contracts already include the former. ${ }^{33}$ In the short run, however, unrest may result and become yet another cost of adapting to an inflationary environment.

32. See Harry Ober, "Occupational Wage Differentials, 1907-1947," Monthly Labor Review, vol. 67 (August 1948), pp. 127-34; and Paul G. Keat, "Long-Run Changes in Occupational Wage Structure, 1900-1956," Journal of Political Economy, vol. 68 (December 1960), pp. 584-600.

33. The current major telephone agreement contains an escalator providing a combination of percentage and flat adjustments. See "Wage Highlights," Current Wage Developments, vol. 29 (September 1977), p. 1. Deere \& Company departs from the practice of other farm machinery manufacturers by using a percentage escalator. See "Wage Highlights," Current Wage Developments, vol. 28 (December 1976), p. 1. 
Mid-1970s. Table 2 permits an analysis of a possible structural shift in wage determination in the 1970 s. A dummy variable, $D 7376$, has been added to some equations; it is equal to one for contracts beginning in the period 1973-76, and zero otherwise. ${ }^{84}$ The period $1973-76$ starts with a remarkable surge in food prices in 1973, which was reinforced later in the year by the oil price increases established by the Organization of Petroleum Exporting Countries. It includes actual shortages of meat and gasoline associated with price controls and the oil embargo as well as a large increase in the unemployment rate. Some observers have associated the period with a break in the cyclically adjusted trend rate of productivity

34. At first glance, it might seem desirable to include a dummy for the impact of the controls program that began in 1971. However, the 1971 contracts in the sample were either concluded before controls or based on precontrol conditions and allowed to operate intact by the Pay Board. A number of aerospace contracts were reduced, but the effect was simply to delay payment from the first to the second year of the contract. (And even the lost money was eventually restored by a court decision.) The longshoremen's contracts were also cut, but they recovered their money when controls expired in 1974. Only two contracts in the sample-both in textileswere negotiated in 1972 when Phase II controls were fully effective. When a dummy for 1972 is added to equations 1 and 3 in table 2, it produces a negative coefficient for FIRST (significant at the 10 percent level) and a nonsignificant negative coefficient for LIFE. But it may simply be picking up other influences-such as importsof special importance to wage setting in the textile industry. Besides these considerations, it has been argued that the purpose of the controls was not to create subnormal wage increases (negative dummy coefficients) but rather to restore wage determination to what was considered to be normal at the time. If so, negative coefficients should not be expected. See Weber and Mitchell, The Pay Board's Progress, pp. 306-15. In any case, the onslaught of price increases in early 1973 and the loosening of controls in Phases III and IV tended to dissipate the impact of wage controls, although as will be noted below, the expiration of controls in April 1974 triggered some wage reopenings.

If 3 is estimated with annual dummies for 1972-76, the following pattern of coefficients for the dummies is obtained.

$\begin{array}{ccc}\text { Year } & \begin{array}{c}\text { Coefficient of } \\ \text { dummy }\end{array} & \begin{array}{c}\text { Number of } \\ \text { observations }\end{array} \\ 1972 & -0.78 & 2 \\ 1973 & 2.98 & 8 \\ 1974 & 1.86 & 11 \\ 1975 & 1.63 & 2 \\ 1976 & 0.34 & 1\end{array}$

Only the dummies for 1973 and 1974 are statistically significant. The lack of significance in the later years may be due to the extreme thinness of the sample after 1974. 
improvement. ${ }^{85}$ Thus it is natural to wonder if the structure of union wage determination might have been altered by these dramatic events.

If the structure of wage determination was in fact altered in an inflationary direction during this period, a further question arises. It is possible that the effect was permanent so that current wage determination is still affected by a structural shift that occurred several years ago. Another possibility, however, is that there was a temporary structural shift in wage determination during the mid-1970s, which later disappeared. Unfortunately, because the contract data end in the mid-1970s, there is no way of differentiating between these alternatives statistically.

An additional consideration is that the dummy technique is crude and raises methodological problems. A period such as 1973-76, when explanatory variables take on extreme values, is of obvious statistical interest. If the underlying parameters do not shift during such periods, the extreme observations should help establish accurate estimates. When dummy variables are used to explain such periods, parameter estimates are weakened and may be distorted. However, the risk of this distortion is somewhat reduced in a contract data base (compared with the time-series data of the type used for table 1) because of the large number of observations.

On the assumption that $D 7376$ is not distorting the estimated impact of the other variables, the dummy coefficient does suggest that wage increases were abnormally high during 1973-76. Equation 4 suggests that for the overall sample, wage changes averaged 2.4 percentage points above what would have been expected over the life of the contract. None of this effect appeared to stem from the first-year increment.

An obvious question is whether escalator increases were the source of the shift. Although the COLA coefficient should capture the escalator effect, it is conceivable that escalator formulas were sufficiently liberalized when inflation became severe to cause an underestimate of the direct impact of inflation on escalated contracts. The deferred portion of escalated contracts does show a 1.6 dummy coefficient, but not enough to make the dummy coefficient significant for the life of the contract (equation 12). However, the dummy is also positive and significant (23) for long-term nonescalated deferred increases, suggesting that the unexplained shift is not merely an escalator phenomenon.

35. Edward F. Denison, "Where Has Productivity Gone?" Basis Point, vol. 3, no. 1 (1978), pp. 11-13. 
The coefficient for $D 7376$ is largest for the life-of-contract increases under short-term contracts (8). Seven contracts within the short-term group began in the 1973-76 period. All but one of these was associated with scheduled or unscheduled reopenings of existing agreements due to the sudden rise in inflation, the end of controls, or both.

The reopener phenomenon has three important effects on the data. First, under the rules adopted for constructing the data, a contract was deemed to end either at its official expiration date or at a wage reopening, whichever came first. Thus reopeners tend to turn long-term contracts into short-term ones, and any structural shifts that were associated with reopening will thereby tend to be associated with the equations for shortterm contracts. Reopeners can also make what were originally frontloaded contracts (FIRST $>$ LIFE) into de facto back-loaded contracts $(F I R S T<L I F E)$. Consider a two-year agreement negotiated in 1973 that provides a 5 percent increase in the first year and a 4 percent increase in the second year. The annual rate of increase over the life of the contract is about 4.5 percent, so that the agreement is front-loaded. If the contract is interrupted by a reopener after fourteen months, the overall 9.2 percent increase $(1.05 \times 1.04=1.092)$ becomes spread over a shorter period of time than initially planned and produces an annual rate of increase of 7.8 percent. Because FIRST is now less than LIFE, the agreement has become back-loaded. Third, although the timing of the reopening in the example just described suggests a disturbance that occurred in 1974, that disturbance becomes associated with a 1973 contract. Hence the reopener phenomenon tends to move the evidence of disturbance to a period prior to the disturbance.

None of the interrupted contracts was escalated. The sudden burst of inflation had not been fully anticipated by parties who presumably were using $p_{-1}$ or some related index as a guide to the future rate of inflation at the time of negotiations. When it became evident that this anticipation was invalid, the contract was interrupted, arithmetically raising its $L I F E$ value and thereby producing a significant and positive dummy coefficient. ${ }^{36}$

36. The arithmetic explanation in the text is not meant to imply that the wage increases recorded were not "real." The point is simply that the costing methodology caused the real effect to be reflected in LIFE or DEFERRED estimates rather than in the first-year adjustments, and that the impact tends to show up in the contract terminated by the reopener rather than in the new contract. 


\section{Some Implications}

Both the union and nonunion sectors exhibit some sensitivity to business conditions, as represented by the unemployment rate. Even in the nonunion sector, however, the magnitude of the sensitivity is not large. Thus the short-run impact of recession on inflation through its direct impact on the wage-setting process is not likely to be great. Within the union sector, unemployment sensitivity is found mainly in contracts of short duration. It appears that, if sensitivity is desirable, the parties either negotiate on a short-term basis or convert longer-term agreements to shorter ones by interrupting them with wage reopeners. Although the parties can exercise discretion over contract duration, the transactions costs-including strikes-associated with frequent negotiations are a powerful incentive for long contracts. In situations where transactions costs make it clearly optimal to have long-term contracts, sensitivity to short-run business fluctuations in the wage-determination process cannot be expected.

Unionization tends to be accompanied by other industrial and laborforce characteristics that may have an impact on the wage-determination process. To illustrate this point, I ran a series of simple regressions. The annual (year-to-year) percent change in average hourly earnings for 93 selected industries was regressed against annual (year-to-year) change in the CPI lagged one year $\left(p_{-1}\right)$ and the inverse of the unemployment rate $\left(U_{0}^{-1}\right)$ over the period 1954-76 or 1959-76, depending on data availability. A simple average of the coefficients of $U_{0}^{-1}$ over all 93 equations is 12.0.

Taken literally, this mean coefficient suggests that a 1 percentage point increase in unemployment from a 6 percent level would slow wage inflation by an average of about 0.3 percentage point - that is, wage setting is not very sensitive to short-run unemployment changes. Table 4 , however, shows the mean values of various characteristics, including unionization, for industries with below-average and above-average coefficients of $U_{0}^{-1}$. It is apparent that insensitivity to business conditions is associated with unionization, fringe benefits, larger establishments, higher capital-to-labor ratios, less female participation in the work force, and higher wages.

One does not have to be a strict disciple of the dual labor market school of analysis to offer plausible explanations of why these characteristics might diminish wage sensitivity to unemployment. ${ }^{37}$ Unionization

37. For a discussion of the dual labor market approach, see Peter B. Doeringer and Michael J. Piore, Internal Labor Markets and Manpower Analysis (Heath, 
Table 4. Selected Characteristics of Industries, by Sensitivity of Wages to Unemployment, 93 Industries

Mean value

\begin{tabular}{|c|c|c|}
\hline \multirow[b]{2}{*}{ Characteristic and year } & \multicolumn{2}{|c|}{ Wage-unemployment sensitivity } \\
\hline & Above average & Below average \\
\hline Union workers as percent of employment, 1976 & 23.9 & 38.3 \\
\hline $\begin{array}{l}\text { Private fringe benefits as percent of private } \\
\text { compensation, } 1971^{\mathrm{b}}\end{array}$ & 5.9 & 9.1 \\
\hline Number of employees per establishment, 1974 & 64 & 241 \\
\hline Depreciation per employee (dollars), $1973^{\circ}$ & 908 & 2,587 \\
\hline Female workers as percent of employment, 1976 & 36.8 & 21.5 \\
\hline Average hourly earnings (dollars), 1976 & 4.65 & 5.86 \\
\hline Coefficient of $p_{-1}$ in wage equations ${ }^{d}$ & 0.65 & 0.70 \\
\hline
\end{tabular}

Sources: Earnings data and female workers as a percent of employment for 1953-74 are from Bureau of Labor Statistics, Employment and Earnings, United States, 1909-75, bulletin 1312-10 (GPO, 1976). Data for 1975 and 1976 are from Employment and Earnings, vol. 22 (March 1976), and ibid., vol. 24 (March 1977). The unionization rate was estimated by dividing the number of workers in key and nonkey contracts from a BLS computer listing by payroll employment in 1976. (This listing excludes some workers participating in smaller agreements.) Depreciation estimates are from U.S. Internal Revenue Service, Statistics of Income-1973, Corporation Income Tax Returns (GPO, 1977), table 1, and were divided by 1973 payroll employment. Employees per establishment is from U.S. Bureau of the Census, County Business Patterns, 1974: U.S. Summary, CPB-74-1 (GPO, 1977), table 1B. The fringe benefits data are from U.S. Bureau of the Census, Annual Survey of Manufactures, 1970-1971 (GPO, 1973), pp. 143-50.

a. Based on the unemployment coefficient in industry wage equations as described in the text. Of 93 industries, 42 had unemployment coefficients above the mean, and 51 were below it.

b. Excludes legally required fringe benefits such as social security contributions. Data are for manufacturing industries only. Years after 1971 could not be used because of a change in the standard industrial classification code.

c. Excludes ordnance, for which data are not available.

d. The $p_{-1}=$ year-to-year change in the CPI, lagged one year over the period 1954-76 or 1959-76.

brings formal, long-term arrangements that reflect equity considerations. Large plants imply bureaucratic and centralized wage-determination procedures. High capitalization implies that labor costs are a smaller proportion of total costs. And in the face of unionization, high capitalizationwith its accompanying load of heavy fixed costs-may lead to strike vulnerability. Female employees and low-wage employees generally tend to have less of an attachment to the firm in particular as well as to the work force in general and are more likely to take part-time employment. They are less likely to embody specific human capital, and therefore their cost

1971), pp. 163-83; and Michael L. Wachter, "Primary and Secondary Labor Markets: A Critique of the Dual Approach," BPEA, 3: 1974, pp. 637-80. A major difference between dual theorists and their critics is the issue of why certain types of firms and industries have extensive internal labor markets. The explanation is less important for purposes of this article than the observation that these firms have such markets. 
of turnover to the employer is reduced. Fringe benefits tend to tie the employee to the employer and make turnover costly.

The differential levels of sensitivity of wage setting to business conditions have obvious implications for public policy. Traditionally when inflation rates are high, anti-inflation policy has relied heavily on demand restraint. If certain groups do not react to such restraint, other groups must be made to react more strongly, given a particular disinflation target. In other words, in periods when policy is aimed at reducing inflation, the insulation of wage determination from real business conditions means that deeper recessions are required to fight inflation, that disinflation goals must be more moderate, or that some means other than simple demand management must be sought to curb inflation. In a period of low inflation, the insulation of wages from real business conditions allows unemployment to be reduced without adding much to inflation, at least in the short run.

\section{CONTRACT DURATION}

Because insulation is associated with contract duration, it must be assumed that the insulated portion of the union sector has grown since the 1940s and 1950s. Long-term labor contracts represent an innovation usually associated with the contract in 1948 between General Motors and the United Automobile, Aerospace and Agricultural Implement Workers of America. The automobile example gradually was adopted in other sectors during the 1950s and 1960s and has become the norm in much of the union sector. In 1975, for example, of the 1,514 major private agreements known to the BLS, only 83 were less than twenty-four months in duration. ${ }^{28}$ The short-term agreements shown in table 2 that provide the overall union sector with significant life-of-contract sensitivity to the unemployment rate tend to be concentrated in the earlier part of the period investigated. Reopeners, which can effectively shorten long-term contracts, are generally associated with inflation rather than with unemployment.

An option for public policy might be a deliberate program of shorten-

38. Bureau of Labor Statistics, Characteristics, p. 7. As late as 1962 , long-term contracts with deferred increments and escalators were considered a sufficient novelty to induce the Brookings Institution to publish a book on the subject. See Joseph W. Garbarino, Wage Policy and Long-Term Contracts (Brookings Institution, 1962). 
ing labor agreements. At present, although long-term agreements are usually considered desirable, the only public policy that actively encourages their use-the "contract bar rule" of the National Labor Relations Board-probably has little impact on the behavior of the parties where collective bargaining relationships have been longstanding. ${ }^{39}$ Thus the development of the long-term agreement can be viewed primarily as a private response of the parties themselves. If parties who would usually choose a long-term contract are forced to negotiate one-year agreements, it is not clear that they would behave in the same manner as parties who voluntarily chose such arrangements.

Forced shorter durations might not bring about more wage sensitivity to business conditions, but would almost certainly result in a substantial increase in strike activity. Some statistical studies have been conducted to explain the propensity to strike. ${ }^{40}$ What is not fully appreciated is the degree to which the number of workers involved in strikes in a given period is simply a reflection of the number of workers under expiring contracts. ${ }^{41}$ Over the period $1968-75,68$ percent of workers affected by stoppages were involved in strikes over renegotiation issues. ${ }^{42}$ Moreover, the recent record in certain industries suggests that some strike activity is almost inevitably linked to contract expiration. Among others, these include the automobile and rubber industries. And after the coal strike of late 1977 and early 1978, most policymakers would probably prefer not to deal with annual coal negotiations.

\section{ESCALATORS}

The question of escalator clauses is closely related to the issue of contract duration. Escalators are typically associated with long-term con-

39. The contract bar rule provides that the National Labor Relations Board will not consider petitions from rival unions or for decertification of a union during the life of a contract less than two years in duration. Threat of controls may also be an inducement to negotiate long-term arrangements and escalators because control authorities may be expected to make exceptions for increments under such contracts.

40. Orley Ashenfelter and George E. Johnson, "Bargaining Theory, Trade Unions, and Industrial Strike Activity," American Economic Review, vol. 59 (March 1969), pp. 35-49; Albert Rees, "Industrial Conflict and Business Fluctuations," Journal of Political Economy, vol. 60 (October 1952), pp. 371-82.

41. Bruce E. Kaufman, "The Propensity to Strike in American Manufacturing," in Barbara D. Dennis, ed., Proceedings of the Thirtieth Annual Winter Meeting, 1977, Industrial Relations Research Association Series (IRRA, 1978), pp. 419-26.

42. U.S. Bureau of Labor Statistics, Analysis of Work Stoppages, various issues. 
tracts and, indeed, help to make long-term contracts possible..8 Debate has occasionally arisen over whether escalators are inflationary. ${ }^{44}$ Escalators-especially quarterly escalators-obviously hasten the impact of price on wages. But except for very short periods, it is not clear that this adds to inflation, unless asymmetries can be adduced in response to pricewage shocks. Escalators undoubtedly influenced and may have enlarged the adjustment of wages to the OPEC price increases of late 1973. But in years such as 1976 , when the relatively slow rise in food prices reduced the rate of inflation dramatically, escalated wages quickly reflected this movement. Tables 1 and 2 suggest that nonescalated union wages and nonunion wages also are influenced by price movements. ${ }^{45}$ Thus a hypothetical banning of escalator clauses would not break the wage-price linkage. But previously escalated agreements would probably be shortened in average duration in the absence of escalators, thus raising strike activity. It is uncertain whether negotiators who previously used a formula to tie their wages to prices could continue to obtain the net results of escalation through frequent contract renegotiation.

\section{WAGE PATTERNS}

Relative wage standing seemed to play a role in the equations based on contract data in table 2 . Even when the coefficient of $R E L$ was not significant, it was always negative. In crude equations such as those used to separate industries by unemployment sensitivity in table 4 the addition of a relative wage variable usually produces a negative coefficient. ${ }^{46}$ What

43. In a sample of major contracts in 1975,11 percent of the agreements for less than twenty-four months had escalators, compared to 35 percent of contracts for twenty-four to thirty-five months and 49 percent of contracts for thirty-six months and longer. See U.S. Bureau of Labor Statistics, Characteristics, p. 47.

44. H. M. Douty, Cost-of-Living Escalator Clauses and Inflation, U.S. Council on Wage and Price Stability (GPO, 1975); Robert H. Ferguson, Cost-of-Living Adjustments in Union-Management Agreements, bulletin 65 (Cornell University, State School of Industrial and Labor Relations, 1976), pp. 43-47.

45. In table 4 the equations used to separate industries by unemployment sensitivity had a mean coefficient for $p_{-1}$ of 0.67 . If industries above (below) that level are grouped, their average unionization rate is 35.4 percent ( 28.5 percent). Thus union wages appear somewhat more sensitive to prices than nonunion wages. But there is obviously considerable overlap between the two groups.

46. A variable was added to the 93 equations consisting of the ratio of hourly earnings in each industry to average hourly earnings for the entire sample, and the ratio was lagged one year. This variable was standardized by dividing it by the 1958 ratio. The equations were run for the period 1959-76. Negative signs appeared in 71 of the 93 cases. 
this suggests is that some force or combination of forces tends to drive, or herd, industries together. This is not a new finding. It has been known for some time that hourly earnings across industries tend to retain their relative ranking, even over very long periods. ${ }^{47}$

The finding of a herd instinct in wage setting probably has less significance for anti-inflation efforts than some policymakers appear to believe. Recently economists have become interested in the influence of pattern bargaining (wage-imitation) in wage determination. It is known, for example, that certain groups of industries seem to tie their bargaining outcomes together. For example, automobiles, automobile parts, trucks, and farm machinery form a sphere of wage determination.48 Various factors may help to explain the existence of this sphere: a common union, intercompany sales, geographic proximity, and product-market competition (for example, Ford makes tractors; International Harvester makes trucks). There seems to be a metals sphere that ties together wages in basic steel, nonferrous metals, metal mining, and metal containers. Yet another sphere appears to center around the national master freight agreement of the International Brotherhood of Teamsters, Chauffeurs, Warehousemen and Helpers of America, which influences wages in smaller trucking settlements, warehousing, and to some extent, retail food. Thus in reviewing the outcome of the automobile, steel, or trucking settlements in 1979 and 1980 , policymakers obviously should put a multiplier coefficient on the number of workers affected by each agreement.

Yet it is apparent from recent statements that policymakers sometimes operate on the assumption that there is a strong, well-defined linkage among the spheres, so that manipulating one contract will manipulate all. In particular, much emphasis has been placed on the Teamsters' negotiation due to take place in early $1979 .{ }^{4 \theta}$ Little definitive evidence exists to support this view. It is known that wage adjustments across industries are

47. Donald E. Cullen, "The Interindustry Wage Structure, 1899-1950," American Economic Review, vol. 46 (June 1956), pp. 353-69.

48. Dunlop refers to such spheres as "wage contours." Arthur Ross calls them "orbits of coercive comparison." See John T. Dunlop, "The Task of Contemporary Wage Theory," in John T. Dunlop, ed., The Theory of Wage Determination (London: St. Martin's Press, 1964), p. 17; Arthur M. Ross, Trade Union Wage Policy (University of California, Institute of Industrial Relations, 1948), p. 53.

49. Barry Bosworth, director of the Council on Wage and Price Stability, is quoted as stating that if "we could get the Teamsters to agree to 20 percent for three years, the United Auto Workers would sign a contract for the same thing. So would steel. Each of these unions wants what the other one has got." See Hobart Rowen, "Bosworth Says U.S. Fumbles Rail Talks," Washington Post, June 16, 1978. 
highly intercorrelated, but this observation does not say much about what causes the similarity. Indeed, wage changes and price changes are so highly correlated that it is difficult to distinguish wage-wage from pricewage inflation, using equations such as those of tables 1 and $2 . .^{\text {so }}$

There are obviously common factors affecting all industries, such as the rate of price inflation. In construction, where the occurrence of wage imitation has been well documented, attempts to trace the precise patterns have met with mixed results. ${ }^{51}$ Outside construction the issue is quite nebulous. ${ }^{52}$ In the absence of general guidelines, it might be argued that holding back the Teamsters, if it could be done, could not hurt in terms of slowing wage inflation; but it is not clear that it would help. An economic unit that considered the Teamsters' settlement as a relevant guide to its behavior might abandon that plan if the Teamsters were subject to obvious government manipulation. And in any case, no one knows what the result of the Teamsters' ripple effect will be after it leaves the immediate sphere of influence..$^{53}$

50. Within the contract data, the correlation coefficient, $R$, between $p_{-1}$ and $w_{-1}$ is 0.8 , where the latter is the year-to-year rate of change in the hourly earnings index for production and nonsupervisory workers in the private nonfarm economy. For shortterm contracts the coefficient is 0.6 ; for long-term escalated contracts, 0.9 ; and for longterm nonescalated contracts, 0.9 . The wage-wage equivalent to 4 of table 2 is

$$
\begin{gathered}
L I F E=15.80+0.54 w_{-1}+10.58 U_{0}^{-1}+0.42 C O L A-16.38 R E L+2.53 D 7376 . \\
\bar{R}^{2}=0.52 ; \text { standard error }=2.01 .
\end{gathered}
$$

(All coefficients are significant at a level of 5 percent or more.) The equation's coefficient of determination is marginally lower and the standard error is marginally higher than those of 4 , but the discrepancy is negligible. In some equations, the wage-wage version is a slight "winner" of the $\bar{R}^{2}$ contest; in others it is a slight "loser." Much the same is true of the manufacturing wage equations of table 1 . The correlation coefficient of $p_{-1}$ and $w_{-1}$ during the period $1960-76$ is 0.9 .

51. See David E. Shulenburger, "Wage Leadership and Patterns of Wage Settlement in Construction," in Proceedings of the Thirtieth Annual Winter Meeting, IRRA Series, pp. 185-92.

52. For example, after an empirical investigation, Y. P. Mehra finds little support for the wage spillover hypothesis in manufacturing. See his "Spillovers in Wage Determination in U.S. Manufacturing Industries," Review of Economics and Statistics, vol. 58 (August 1976), pp. 300-12.

53. A recent review of the literature on spillover and wage rounds concluded that "the apparent variability of round phenomena makes it useless as a forecasting device.... Without a theory of the wage round, the concept can only be applied in a retrospective fashion, as a valuable tool of historical explanation perhaps-but not as a tool of economic science." John Burton and John Addison, "The Institutionalist Analysis of Wage Inflation: A Critical Appraisal," in Ronald G. Ehrenberg, ed., Research in Labor Economics: An Annual Compilation of Research, vol. 1 (JAI Press, 1977), p. 366. 
Sometimes the word "pattern" is used to describe the spread of innovative arrangements. For example, after the United Auto Workers negotiated a supplemental unemployment benefits program with the automobile industry in 1955, the idea was adopted in other industries. The current contract of the Chrysler Corporation with the United Auto Workers contains an embryonic legal services plan which, if proved successful, might provide a model for such programs elsewhere. Innovative patterns in compensation are not confined to unions; the spread of executive stock option plans is an example from the nonunion sector. However, the main point about innovative patterns is that they involve the structure of the compensation package rather than the magnitude. Policymakers should not assume that such patterns are symptoms of magnitude patterns.

Economists are primarily concerned with magnitude patterns. And here contradictory anecdotal evidence can be cited. It is known, for example, that immediately after World War II, rounds of wage settlementsexpressed in cents per hour-occurred in diverse industries, beginning with an eighteen-and-one-half-cent round in 1946. This type of behavior was reinforced by the judicial review process of the wage controls of World War II (and later the Korean War) in which principles of precedence and equal treatment tended to tie settlements together. Since that time, however, some developments have weakened the tendency to follow patterns. Among these are the increased complexity of the compensation package relative to the standard, one-year, flat increases of the 1940s. Fringe benefits, work rules, and variegated escalator formulas make crossindustry comparisons more difficult. And the once-tight administrative linkage between the old CIO industrial unions has been loosened.

Policymakers ought to be cautious about accepting the folk wisdom of industrial relations. Government officials consoled themselves with the widely accepted view that the large coal settlement of March 1978 was not generally thought to set a pattern. On the one hand, that settlement might have conveyed to the Teamsters that government resolve quickly crumbles in the face of economic disruption. Did not workers in the petroleum industry (who will negotiate in January 1979) also learn from that settlement about the potential for wage increases in the energy field, even in the face of a significant nonunion sector? On the other hand, until the mid-1960s, it was believed that the United Rubber, Cork, Linoleum and Plastic Workers of America followed the settlements in the automobile industry at the major tire companies. After that, management in the rub- 
ber industry appeared to break the linkage, resulting in a string of rubber settlements in which wages rose less rapidly than those in the automobile industry.

In the context of guidelines or a program of formal controls, visible settlements will be watched by other economic units for indications that the government will enforce the standards strictly or that the guidelines can be ignored with impunity. Since the guidelines will be in effect in 1979 , the Teamsters' negotiations must now be regarded as a key settlement, simply because they will come early in the year and will be widely reported in the news media. But under usual circumstances the herd phenomenon in wage determination does not provide policymakers with definitive guides on where direct intervention might yield important leverage. If jawboning is believed to be desirable, a general guideline (ideally one determined through a consultative process), combined with pressures on as many settlements as possible, would seem the appropriate course of action. The alternative of trying to identify the key settlement is risky at best.

\section{Outlook for Union Wage Determination in 1979}

As is generally the case, a significant proportion of union workers in 1979 will experience wage increases that have been stipulated in existing contracts. As of early September 1978, the BLS had information on 4.1 million private-sector workers in the major union sector who are slated for some form of deferred increase in $1979 .{ }^{54}$ Another 2 million workers were either negotiating, about to negotiate, or concluding contracts for which data were not yet available. Based on preliminary tabulations, deferred wage adjustments under nonescalated contracts are expected to average 6.7 percent. Escalated contracts will provide adjustments, excluding escalator payments, averaging 3.7 percent. If it were assumed that the escalators under these contracts provided the recent average of 57 percent inflation protection and that the rate of inflation was about $7 \frac{1}{2}$ percent, the combination of deferred and escalator payments would be about 8 percent. ${ }^{55}$ Wages in the deferred sector would then rise approximately $7 \frac{1}{2}$ percent. On average, workers under deferred agreements would

54. Victor J. Sheifer of the BLS supplied these estimates.

55. The 57 percent estimate is from Sheifer, "Collective Bargaining." 
experience no significant change in real wages. This would not be the outcome if a different rate of inflation prevailed. With 6 percent inflation, the average deferred wage increase (including escalator adjustments) would be about 7 percent, and real wages would rise on average.

Estimates for deferred increases in fringe benefits are not presently available. In 1978, in percentage terms, deferred increases in wages and benefits combined for agreements covering 5,000 or more workers slightly exceeded the increases in wages alone for the entire major union sector. ${ }^{58}$ Because some of those contracts will still contain provision for deferred payments in 1979, it is possible that the relationship will be repeated. And labor costs to all employers will be affected by increased social security payroll taxes in 1979.

In the union sector the principal unknown element is the magnitude of the adjustment under contracts that must be renegotiated. As of late 1977, the BLS already knew of 3.6 million workers in the major union sector whose contracts were set to expire or reopen in 1979.57 About 11 percent of workers under contracts concluded during the first half of 1978 negotiated one-year agreements that will expire in 1979. ${ }^{58}$ Thus the wages of about 4 million workers in the major sector will be negotiated in 1979.

Table 5 presents a summary of the rate of wage increase experienced under the last three contracts of the five negotiating groups likely to receive the majority of public attention (and probably government attention) in $1979 . .^{50}$ Their real wage gains during the 1970s are impressive. In 1973, three of the five slipped behind the marked acceleration in price inflation-as did many other groups in both union and nonunion sectors.

56. LeRoy, "Scheduled Wage Increases," pp. 4-5.

57. Lena W. Bolton, "Bargaining Calendar to be Light in 1978," Monthly Labor Review, vol. 100 (December 1977), p. 37.

58. U.S. Department of Labor, News, USDL-78-656, July 27, 1978, table 6.

59. Most of the cost estimates in the table come from data published by the U.S. Council on Wage and Price Stability. In developing estimates of the 1976 settlements, the council assumed CPI inflation of 6 percent a year to obtain the escalator effect. The figures in table 5 are based on an assumption of a rise of 7 percent a year in the CPI and include an allowance for the additional "roll-up" effect on fringe benefits (the indirect effect of a wage increase on fringe benefits) when wage and benefit estimates are given. Data on the 1970 meat-packing contract are based on increments reported by the BLS in Wage Chronology: Armour and Company, 1941-72 (GPO, 1971) and in a 1975 supplement to this bulletin. The base wage for the 1970 contract was extrapolated backward from an estimate by the Council on Wage and Price Stability. 
Table 5. Estimates of Annual Rate of Wage Increases under Selected Collective Bargaining Agreements, 1970, 1973, and 1976

Percent

\begin{tabular}{|c|c|c|c|c|c|}
\hline \multirow[b]{2}{*}{ Parties to the agreement } & \multirow[b]{2}{*}{$\begin{array}{l}\text { Compensation } \\
\text { index }\end{array}$} & \multicolumn{2}{|c|}{$\begin{array}{c}\text { Life of } \\
\text { the contractb }\end{array}$} & \multicolumn{2}{|c|}{1976} \\
\hline & & 1970 & 1973 & $\begin{array}{l}\text { Life of } \\
\text { the con- } \\
\text { tract }\end{array}$ & $\begin{array}{l}\text { First } \\
\text { yeard }\end{array}$ \\
\hline $\begin{array}{l}\text { Trucking Employers, Inc., } \\
\text { and Teamsters }\end{array}$ & $\begin{array}{l}\text { Wages } \\
\text { Wages and benefits }\end{array}$ & $\begin{array}{l}12.7 \\
12.6\end{array}$ & $\begin{array}{l}6.6 \\
7.9\end{array}$ & $\begin{array}{l}10.1 \\
10.4\end{array}$ & $\begin{array}{l}9.1 \\
9.7\end{array}$ \\
\hline $\begin{array}{l}\text { General Electric Company } \\
\text { and Electrical Workers } \\
\text { (IUE) }\end{array}$ & Wages & 6.7 & 6.6 & 10.4 & 13.1 \\
\hline $\begin{array}{l}\text { "Big five" rubber com- } \\
\text { panies and United } \\
\text { Rubber Workers }\end{array}$ & $\begin{array}{l}\text { Wages } \\
\text { Wages and benefits }\end{array}$ & $\begin{array}{l}7.1 \\
\cdots\end{array}$ & $\begin{array}{l}5.5 \\
\cdots\end{array}$ & $\begin{array}{l}12.2 \\
10.4\end{array}$ & $\begin{array}{r}17.1 \\
\ldots\end{array}$ \\
\hline $\begin{array}{l}\text { "Big three" automobile } \\
\text { companies }{ }^{f} \text { and United } \\
\text { Auto Workers }\end{array}$ & $\begin{array}{l}\text { Wages } \\
\text { Wages and benefits }\end{array}$ & $\begin{array}{l}8.7 \\
\cdots\end{array}$ & $\begin{array}{l}9.7 \\
\cdots\end{array}$ & $\begin{array}{r}9.1 \\
10.4\end{array}$ & $\begin{array}{l}5.9 \\
8.3\end{array}$ \\
\hline $\begin{array}{l}\text { Major meat packers and } \\
\text { meat cutters }\end{array}$ & Wages & 6.6 & 12.1 & 8.5 & 2.4 \\
\hline Addenda & & & & & \\
\hline $\begin{array}{l}\text { Consumer price index } \\
\text { Hourly earnings index }\end{array}$ & $\begin{array}{l}\cdots \\
\cdots\end{array}$ & $\begin{array}{l}4.4 \\
6.5\end{array}$ & $\begin{array}{l}8.7 \\
8.1\end{array}$ & $\begin{array}{l}7.0^{h} \\
\cdots\end{array}$ & $\begin{array}{l}6.9 \\
7.1\end{array}$ \\
\hline
\end{tabular}

Sources: Wage increases are derived from data in U.S. Council on Wage and Price Stability press releases CWPS-189, September 24, 1976; CWPS-225, January 13, 1977, and "1976 Collective Bargaining Negotiations: A Background Paper," January 1976; Bureau of Labor Statistics, Wage Chronology: Armour and Company, 1941-72, bulletin 1682 (GPO, 1971), table A, and Wage Chronology: Armour and Company and Amalgamated Meat Cutters and Butcher Workmen of North America, September 1973-August 1976, supplement to bulletin 1682 (BLS, 1975). The increases in the CPI and earnings index are from official BLS data.

a. The official names of the labor unions appear in appendix table A-1.

b. Includes escalator payments.

c. Includes escalator payments on assumption of an increase of 7 percent a year in the CPI.

d. Excludes escalator payments.

e. Firestone Tire and Rubber Company, General Tire and Rubber Company, B. F. Goodrich Company, Goodyear Tire and Rubber Company, and Uniroyal, Inc.

f. Chrysler Corporation, Ford Motor Company, and General Motors Corporation.

g. June-to-June basis, 1970-73, 1973-76, 1976-79, 1976-77, respectively.

h. Assumed. See note c above.

But those who slipped in 1973 appeared to have recovered lost ground in their 1976 contracts.

The underlying conditions in the five groups are quite varied. Only the Teamsters are capable of creating a true "national emergency" dispute. The BLS records on union contracts in trucking and warehousing (SIC 42) show that about half of the payroll employment in the industry is 
unionized. ${ }^{80}$ Yet it would be a mistake to assume that the nonunion sector of trucking could easily take up the slack in the case of a strike. Trucking is an interconnected industry in which disruptions at one location can quickly tie up others. Indeed, this interconnection has historically been an important technique of the Teamsters in organizing nonunion trucking companies and firms in other industries that rely on trucks. ${ }^{61} \mathrm{~A}$ national trucking strike would quickly divert government attention to the issue of halting and settling the dispute through the use of a Taft-Hartley act injunction or by other means. The question of wage restraint could easily be forgotten under the pressures that a strike would create.

Electrical manufacturing and meat packing both have substantial nonunion capacity. Moreover, not all union workers are covered by the master agreement. A strike in either industry would obviously disrupt production, but nonstriking plants are often not dependent on supplies from striking plants and can continue in operation. Several unions participate in bargaining in the electrical manufacturing industry, a factor that at one time prevented a united front on the labor side. Since the late 1960s, however, the unions have coordinated their efforts. ${ }^{62}$

In the rubber industry, the United Rubber Workers represents the majority of union workers employed; the industry is heavily, but not exclusively, unionized. However, the union has a tradition of decentralization, so that demands at the major companies are not always closely coor-

60. This estimate of unionization is obtained by dividing the BLS estimate of workers covered by union agreements as of early 1978 by 1977 payroll employment. Because the BLS estimates are made at the time of negotiations, earlier employment must be used. These estimates are reasonably complete for agreements covering 1,000 or more workers, but are incomplete for smaller contracts. Thus the figures underestimate total union coverage.

61. See Ralph and Estelle James, "Hoffa's Leverage Techniques in Bargaining," Industrial Relations, vol. 3 (October 1963), pp. 73-93.

62. The General Electric Company followed a practice known as "Boulwarism" during the 1950s and early 1960s (placing its intended final offer on the table in the initial stages of bargaining). The company would then adamantly hold to the offer unless the unions could provide technical arguments to convince the company that it should modify its position. Many of the unions at General Electric agreed to coordinate their bargaining during the 1966 negotiations, but the company did not change its tactics. In the 1969 negotiations, however, the unions-spurred by favorable court decisions and support from the AFL-CIO-were able to induce a noticeable improvement in the company's offer. See Abraham Cohen, "Coordinated Bargaining at General Electric: An Analysis" (Ph.D. dissertation, Cornell University, 1973). 
dinated. Those companies have formed a pact of mutual aid that provides financial assistance to firms on strike. Strikes in the rubber industry can be long and bitter. But experience in the 1976 strike suggests that the economic effects can be confined largely to the industry itself. At that time, replacement tires were easily available to the general public through inventories, imports, nonunion operations, and nonstriking plants. Tires that were original equipment for new cars posed more of a problem. However, the substitution of a company-issued IOU for the spare tire cut demand by 20 percent and enabled most models of new cars to be delivered.

Automobile strikes traditionally have been aimed at one company at a time. When General Motors is the target company, its sheer size can have noticeable impact on the national income accounts, as it did during the 1970 walkout. ${ }^{\text {ss }}$ Virtually all production workers in the industry are unionized, and most belong to the United Auto Workers. Inventory buildups prior to strikes are difficult because of the cost and timing of new model automobiles. And the union has a reputation for being disciplined and coordinated during negotiations. Imports are a factor in the product market, but recent movements in exchange rates have weakened foreign competition. And the new Volkswagen plant in Pennsylvania has already been unionized. ${ }^{64}$

No model can yield forecasts of the outcomes of specific contracts on which any confidence can be placed. However, the equations of table 2 can be used to project changes in average union wages, providing assumptions are made about the underlying explanatory variables. Because the COLA variable is one of these and because it may be influenced by the bargaining outcomes themselves-as well as by other public policy measures-one can ask whether the projected outcomes seem consistent with the assumed movement of prices in the future. This question will be addressed below. Initially it will be assumed that no guidelines were to be in effect. A discussion of the impact of the guidelines follows.

63. Annual GNP fell by $\$ 10.6$ billion from $1970: 3$ to $1970: 4$ in 1972 dollars. Gross automobile output fell by $\$ 11.7$ billion.

64. Volkswagen remained entirely neutral during the representation election and was complimented by the union for its stance. See "Auto Workers File for Representation Vote at Volkswagen in Pennsylvania," Bureau of National Affairs, Daily Labor Report, May 17, 1978, p. A-2. The United Auto Workers enjoy good relations with their counterparts in the German union who have representation on various boards of the parent firm under Germany's "codetermination" system. 
Table 6. Estimated Union Wage Changes in the Absence of Guidelines, 1979"

Percent

\begin{tabular}{|c|c|c|c|c|c|c|}
\hline \multirow[b]{3}{*}{$\begin{array}{l}\text { Duration of } \\
\text { contract }^{\mathrm{b}}\end{array}$} & \multicolumn{3}{|c|}{ No shift in the mid-1970s ${ }^{\circ}$} & \multicolumn{3}{|c|}{ Permanent shift in the mid-1970s } \\
\hline & \multirow[b]{2}{*}{$\begin{array}{c}F I R S T^{\mathrm{d}} \\
(I)\end{array}$} & \multicolumn{2}{|c|}{ LIFE } & \multirow[b]{2}{*}{$\begin{array}{l}F I R S T^{\mathrm{d}} \\
\quad(4)\end{array}$} & \multicolumn{2}{|c|}{ LIFE } \\
\hline & & $\begin{array}{l}\text { Without } \\
\text { escalator } \\
\text { provisions } \\
(2)\end{array}$ & $\begin{array}{c}\text { With } \\
\text { escalator } \\
\text { provisions } \\
(3)\end{array}$ & & $\begin{array}{c}\text { Without } \\
\text { escalator } \\
\text { provisions } \\
(5)\end{array}$ & $\begin{array}{c}\text { With } \\
\text { escalator } \\
\text { provisions } \\
(6)\end{array}$ \\
\hline All durations & 7.5 & 6.1 & 8.1 & 7.4 & 7.2 & 9.0 \\
\hline Short-term & 4.9 & 5.5 & 5.5 & 5.2 & 6.5 & 6.5 \\
\hline \multicolumn{7}{|l|}{ Long-term } \\
\hline Escalated & 9.0 & 5.9 & 9.9 & 8.8 & 7.1 & 10.3 \\
\hline Nonescalated & 8.2 & 6.5 & 6.5 & 7.8 & 7.2 & 7.2 \\
\hline
\end{tabular}

Source: Based on equations of table 2.

a. See text for the assumptions underlying these projections.

b. Short-term contracts are for eleven to seventeen months; long-term, eighteen or more months.

c. The no-shift projections use equations from table 2 without $D 7376$. The permanent-shift projections use equations from table 2 with $D 7376$, maintaining the value of $D 7376$ at 1.0 in the projections. LIFE and FIRST are defined in table 2, note b.

d. Escalator increases are excluded.

\section{PREGUIDELINE OUTLOOK}

Table 6 provides a projection of 1979 wage outcomes based on the equations of table 2 . It is assumed that the lagged inflation variable $\left(p_{-1}\right)$ takes on a value of 7.3 percent, that unemployment averages 6.2 percent, that price change during the life of the contract averages 7.5 percent a year, and that the relative wage variable $(R E L)$ has a value of 1.05 in $1979 .{ }^{65}$ Even with these assumptions, table 2 leaves an open question.

65. The 7.3 percent estimate for $p_{-1}$ is based on the assumption that inflation during 1978 will taper off in the latter part of the year, producing a December-toDecember rate of about 8 percent. The unemployment rate of 6.2 percent shows a slight increase above the level at the time this article was prepared. An increase of a full 1 percentage point to 7.2 percent would reduce the overall predictions for FIRST by only 0.4 percentage point and the $L I F E$ predictions by even less. The assumption that inflation will average 7.5 percent over the three years beginning in 1979 is arbitrary and based largely on the assertion that was commonly voiced prior to the guidelines that the "underlying" rate of inflation was in the range of 7 to 8 percent. Note that in the overall equations the COLA variable is zero for nonescalated contracts. It was assumed that escalated contracts would cover about 60 percent of the workers negotiating contracts in 1979. Hence, COLA was inserted in the overall equations as 7.5 percent multiplied by 0.60 . The 60 percent figure is the average number of workers estimated to be under escalated contracts during the period 1976:1 through 1978:2 
Some equations in table 2 were estimated on the assumption that a shift occurred in the wage-setting process toward the end of the observation period, as reflected in $D 7376$. Obviously, alternative assumptions about the nature of the shift-whether it was permanent or temporary or whether it existed at all-will result in differing projections.

As already noted, the timing of the possible shift in the mid-1970s unfortunately coincided with a period of extreme values of the price and unemployment variables. The dummy is undoubtedly "stealing" some of its significance from the other explanatory variables. In the case in table 2 in which $D 7376$ produced a significant coefficient, the coefficient of the lagged price change and COLA variables fell in magnitude. This tendency is especially noticeable for the short-term contracts in which the coeffcient of the lagged price change drops from 0.77 to 0.06 . Where the unemployment coefficient was significant, a significant dummy coefficient also lowered its magnitude. In short, while the equations without the dummy may be somewhat biased by not reflecting a possible shift in structure, the equations with the dummy are clearly distorted.

It seems appropriate, therefore, to confine the projections to just two of the possible assumptions about a shift in wage determination in the mid-1970s. The first assumption is that no shift occurred, and that the equations without the dummy can be used to make future projections with reasonable accuracy. A second assumption is that a structural shift in wage determination did occur, and that the effect of this shift is still present. Because of distorting effects of $D 7376$ on the other coefficients,

in the nonconstruction sector. (Nonconstruction was used because the settlements included in the union contract data included no construction situations.) About 12 percent of construction workers were assumed to be under escalator clauses, based on a 1975 BLS survey. The data on workers under escalated agreements and in nonconstruction agreements comes from Current Wage Developments, vol. 29 (April 1977), p. 48; Finger, "Wage-rate Increases," p. 54; and Department of Labor, USDL-78-656, table 1. The estimate of construction workers under escalators comes from Bureau of Labor Statistics, Characteristics, p. 46. The value of $R E L$ posed a special problem. The last value of $R E L$ for each of the seventeen situations in the union contracts used for the table 2 regressions averaged a little less than 1.03 for contracts whose initial date was in the 1973-74 period. Average hourly earnings, lagged one year, are the denominator of $R E L$ (before standardization). This series increased about 55 percent from mid-1972 to mid-1978. Effective mean wage changes in the major union sector were estimated to average just under 60 percent from 1973 to 1978 . (The 1978 figure was the estimate for the first six months of 1978 compounded to an annual rate.) With allowance for rounding, this suggests a value for REL of about 1.05 in 1979. 
projections based on an assumed temporary shift cannot be expected to produce reasonable results. ${ }^{68}$ Hence the projection results in table 6 show only estimates of no shift and a permanent shift.

Obviously the more disaggregated estimates of table 6 are subject to a lesser degree of confidence than the aggregates. For example, the gap between FIRST and LIFE for short-term contracts is wider than what would normally be expected and reflects the wage reopening experience of the mid-1970s. It might be argued that long-term escalated contracts should normally be expected to provide smaller increases in the first year than would long-term nonescalated contracts. But this relative effect does not always appear in actual data. In 1977, for example, major escalated contracts had first-year wage adjustments averaging 8.0 percent, compared with 7.6 percent for nonescalated contracts. ${ }^{67}$ The overall results suggest that an ongoing inflation rate of 7.5 percent beginning in 1979 would be consistent with the wage-rate adjustments over the life of contracts averaging 8 to 9 percent. A softening of business conditions would reduce this projection somewhat.

A more optimistic view of future price inflation would lower the estimates of table 6 through the escalator mechanism. However, because not all contracts have escalators and because lagged price inflation plays an important role in the equations, the impact is limited. For all contracts, the substitution of a 6 percent future price inflation rate for the 7.5 percent assumption of table 6 would reduce the life-of-contract estimates by about 0.4 percentage point.

The estimates for both no shift and a permanent shift in table 6 are based on equations that deal imperfectly with the special circumstances surrounding wage determination in the mid-1970s when controls were lifted and inflation accelerated. Despite the deficiencies in the equations, the projections of table 6 seem plausible. For the first six months of 1978,

66. In some ways 1979 will have characteristics that are similar to the period 1973-76 in terms of the explanatory variables. During 1973-76, the mean value of lagged price change was about 7.4 percent, close to the 7.3 percent estimate for lagged price change in 1979. The mean value of unemployment during 1973-76 was 6.7 percent, which is slightly higher than the 6.2 percent estimate used for 1979 . However, the equations derive most of their power from the price assumptions. Thus even though the dummy distorts the coefficients, its presence in 1979 tends to compensate for the damage. If, however, the dummy were set equal to zero in 1979 (in the case of a temporary shift), the projections would have only the distorted coefficients upon which to rely without the compensating influence of the dummy.

67. See Finger, "Wage-rate Increases," p. 54. 
new long-term contracts established values of LIFE (excluding escalators) of 6.7 percent. For new short-term contracts, LIFE was set at 5.4 percent. For all new contracts, LIFE (excluding escalators) was 6.6 percent. ${ }^{88}$ Negotiators in 1978 were looking back at slightly lower lagged inflation rates than what will characterize 1979. Yet they produced life-ofcontract increases comparable to those of columns 2 and 5 of table 6. The added push of lagged inflation in 1979 should be at least partially offset by the relative wage effect. So the estimates of table 6 appear reasonable.

Although the projected 1979 settlements appear reasonable alongside the results of the 1978 negotiations, there is a question of the consistency between the assumed 71/2 percent price inflation rate for 1979 and the projected life-of-contract wage increases of 8 to 9 percent. It is important to note that the projections of table 6 cover only a small portion of the labor force-that is, workers in the major union sector who will be negotiating new contracts. According to table 6, first-year settlements for these workers will be about $7 \frac{1}{2}$ percent without escalators. Allowance for escalators in the first year, fringe-benefit increases, and increased social security taxes would easily push this figure into the range of 8 to 9 percent. Major union workers under deferred adjustments, as noted earlier, will probably receive wage increases of about $71 / 2$ percent in 1979 . With allowance for social security and fringe benefits, this estimate would rise into the lower end of the 8 to 9 percent range.

If all wages rose at a rate of 8 to 9 percent and if prices rose at $71 / 2$ percent, a moderate but plausible real wage gain would result. Thus wage setting in the nonunion and minor union sectors is crucial to the issue of consistency between the projected wage increases and the assumed price inflation rate. On a total compensation basis, it appears that labor costs in the sector outside the major union work force were also increasing at an underlying rate of 8 to 9 percent during the first half of 1978. Because lagged inflation will be higher in 1979 than it is this year, but will probably be accompanied by rising unemployment, a $7 \frac{1}{2}$ percent estimate of price inflation for 1979 appears reasonably consistent with the anticipated rate of wage inflation in the absence of guidelines.

The new guidelines program features a 7 percent wage standard and a $53 / 4$ percent goal for prices. If every wage adjustment adhered to the

68. Data are from Department of Labor, USDL-78-656, p. 12. 
guidelines, the result would obviously be wage inflation of 7 percent or less. However, the interesting question is whether this is likely to happen-whether guidelines might induce the parties to consider the world a fundamentally different place in which 7 percent would be a "reasonable" target for wages.

What the equations of table 2 cannot answer is the precise structural route by which past inflation affects current wage change. If the lagged price coefficient is viewed as the parties' estimate of the future course of inflation-that is, if they extrapolate the future by reference to the past, then much depends on the credibility of any guidepost program. It is conceivable that the parties might be convinced that the $53 / 4$ percent price goal was a better indicator of the future than the past extrapolation. If so, then $53 / 4$ percent could be substituted for the actual value of $p_{-1}$ in the equations. Under this assumption, the life-of-contract averages for all contracts would center around 7 percent. ${ }^{69}$ The averages would run closer to 8 percent for long-term escalated contracts. This is sufficiently close to 7 percent that some bargainers might be willing to concentrate on noneconomic demands, such as job security, to comply with the official standard.

The critical point is that the optimistic scenario depends critically on convincing people that the recently experienced rate of inflation is not a good guide to the future. Beyond this, it depends on the assumption that the coefficient of $p_{-1}$ does in fact represent a projection process. It is possible that the true process in the labor market is wage-wage, and that the 7 percent wage guideline would plug directly into the parties' utility functions as the desired rate of wage change. But there is no clear evidence on this point. ${ }^{70}$

Absent direct intervention or success from the guidelines program along the lines just described, the projections of table 2 do not suggest that union settlements in 1979 would be very different settlements from those of recent years. Nonconstruction settlements in 1977 over the life of the contract averaged 5.7 percent excluding escalator payments, and 7.0 percent for the first six months of 1978. Table 6 projects a range of 6.1 to

69. This is approximately correct using either the $53 / 4$ percent assumption for price behavior to price out the COLA or the 6 percent that the guidelines program directs the parties to use in estimating the value of escalators in new contracts.

70. It is beyond the scope of this paper to estimate the potential impact of the proposed inflation tax rebate (real wage insurance) on 1979 wage determination. 
7.2 percent for 1979 . The relative wage effect does have a moderating influence on the projections. But none of the estimates include an allowance for fringe benefits, which have boosted the total compensation cost increase relative to the wage-rate increase in recent years. Given these estimates, it is easy to understand why the administration opted for a policy of wage-price guidelines.

\section{AP PENDIX}

Table A-1. Employer-Union Agreements Included in Contract Information, by Standard Industrial Classification of Base Wage Data

\begin{tabular}{|c|c|c|}
\hline $\begin{array}{l}\text { Industry division and employer } \\
\text { or employer association }\end{array}$ & Union & $\begin{array}{c}\text { Standard } \\
\text { industrial } \\
\text { classification }\end{array}$ \\
\hline \multicolumn{3}{|l|}{ Manufacturing } \\
\hline Aluminum Company of America & United Steelworkers of America & $333,334^{b}$ \\
\hline Armour and Company & $\begin{array}{l}\text { Amalgamated Meat Cutters and } \\
\text { Butcher Workmen of North } \\
\text { America }\end{array}$ & 2011 \\
\hline Atlantic Richfield Company & $\begin{array}{l}\text { Oil, Chemical and Atomic Workers } \\
\text { International Union }\end{array}$ & 291 \\
\hline Berkshire Hathaway, Inc. & United Textile Workers of America & 22 \\
\hline $\begin{array}{l}\text { Boeing Company (Washington } \\
\text { plants) }\end{array}$ & $\begin{array}{l}\text { International Association of Machin- } \\
\text { ists and Aerospace Workers }\end{array}$ & 3721 \\
\hline Dan River Inc. & United Textile Workers of America & 22 \\
\hline $\begin{array}{l}\text { Firestone Tire and Rubber } \\
\text { Company }\end{array}$ & $\begin{array}{l}\text { United Rubber, Cork, Linoleum and } \\
\text { Plastic Workers of America }\end{array}$ & 301 \\
\hline Ford Motor Company & $\begin{array}{l}\text { International Union, United Auto- } \\
\text { mobile, Aerospace and Agricultural } \\
\text { Implement Workers of America }\end{array}$ & 371,3711 \\
\hline General Electric Company & $\begin{array}{l}\text { International Union of Electrical, } \\
\text { Radio and Machine Workers (IUE) }\end{array}$ & 36 \\
\hline $\begin{array}{l}\text { International Paper Company } \\
\text { (Southern Kraft Division) }\end{array}$ & $\begin{array}{l}\text { United Paperworkers International } \\
\text { Union }\end{array}$ & 26 \\
\hline $\begin{array}{l}\text { Lockheed Aircraft Corporation } \\
\text { (California) }\end{array}$ & $\begin{array}{l}\text { International Association of Machin- } \\
\text { ists and Aerospace Workers }\end{array}$ & 3721 \\
\hline United States Steel Corporation & $\begin{array}{l}\text { United Steelworkers of America } \\
\text { (continued) }\end{array}$ & 331 \\
\hline
\end{tabular}


Table A-I (continued)

Industry division and employer or employer association

Standard

industrial

ining

\section{Mining}
Anaconda Company (Montana Mining Division)

Bituminous Coal Mine Operators

United Steelworkers of America

United Mine Workers of America

\section{Transportation}

\section{Council of North Atlantic Ship- ping Associations \\ Pacific Maritime Association}

Trucking Employers, Inc.

\section{International Longshoremen's Association \\ International Longshoremen's and Warehousemen's Union \\ International Brotherhood of Teamsters, Chauffeurs, Warehouse- men and Helpers of America}

\footnotetext{
Sources: Data on wage adjustments for General Electric Company and Trucking Employers, Inc., are from Current Wage Developments, various issues. Data for other adjustments are from U.S. Bureau of Labor Statistics, Wage Chronology, for each employer or association, bulletins 1815 and supplement, 1682 and supplement, 1915, 1849 and supplement, 1895, 1934, 1762, 1787 and supplement, 1788 and supplement, 1904, 1814 and supplement, 1736 and supplement, 1960, 1953, and 1799 and supplement, respectively (as listed in the table).

a. The base wage data used in the table 2 regressions are from average hourly earnings for the indicated standard industrial classification, except as noted.

b. Before 1958, an implicit base wage was calculated from information in the BLS Wage Chronology for the Aluminum Company of America and the union, bulletin 1815 (GPO, 1974).

c. The base wage is from the BLS Wage Chronology for North Atlantic longshoremen, bulletin 1736 (GPO, 1972), and supplement.

d. The base wage is from the BLS Wage Chronology for the Pacific Maritime Association and the union, bulletin 1960 (GPO, 1977).

c. The base wage data are from an index of wage rates in the Great Lakes region for truckdrivers and helpers in BLS, Union Wages and Hours: Local Truckdrivers and Helpers (GPO), various issues. The index applies to July 1 of each year and was adjusted for timing from increments reported in various issues of Current Wage Developments.
} 